\title{
Dendrodendritic Electrical Synapses between Mammalian Retinal Ganglion Cells
}

\author{
Soh Hidaka, ${ }^{1}$ Yasushi Akahori, ${ }^{2}$ and Yoshikazu Kurosawa ${ }^{2}$ \\ ${ }^{1}$ Department of Physiology, School of Medicine, and ${ }^{2}$ Division of Immunology, Institute for Comprehensive Medical Sciences, Fujita Health University, \\ Toyoake, Aichi 470-1192, Japan
}

Electrical synapses between $\alpha$-type ganglion cells were detected using combined techniques of dual patch-clamp recordings, intracellular labeling, electron microscopy, and channel subunit connexin immunocytochemistry in the albino rat retina. After intracellular injection of Neurobiotin into $\alpha$-cells of inner (ON-center) and outer (OFF-center) ramifying types, measurement of tracer coupling resulted in a preferentially homologous occurrence among cells of the same morphological type $(n=19 \mathrm{of} 24)$. In high-voltage as well as conventional electron microscopic analysis, direct dendrodendritic gap junctions (average size, $0.86 \mu \mathrm{m}$ long) were present in contact sites between tracer-coupled $\alpha$-cells. In simultaneous dual whole-cell recordings from pairs of neighboring $\alpha$-cells, these cells generated TTX-sensitive sustained spiking against extrinsic current injection, and bidirectional electrical synapses (maximum coupling coefficient, 0.32 ) with symmetrical junction conductance (average, $1.35 \mathrm{nS}$ ) were observed in pairs with cells of the same morphological type. Precise temporal synchronization of spike activity (average time delay, $2.7 \mathrm{msec}$ ) was detected when depolarizing currents were simultaneously injected into the pairs. To address whether physiologically identified electrical synapses constitute gap junctional connectivity between cell pairs, identified neuronal connexin36 immunoreactivity was undertaken in Lucifer yellow-labeled cell pairs after patch-clamp recordings. All $\alpha$-cells expressed connexin36, and confocal laser-scanning imaging demonstrated that connexin36 is primarily located at dendritic crossings between electrically coupled cells (seven sites in a pair, on average). These results give conclusive evidence for electrical synapses via dendrodendritic gap junctions involving connexin36 in $\alpha$ retinal ganglion cells of the same physiological type.

Key words: retinal ganglion cells; dendrodendritic gap junctions; electrical synapses; connexin36; patch clamp; high-voltage electron microscopy; rat retina

\section{Introduction}

Many neuronal networks in the mammalian CNS provide direct cell-to-cell communication, conduction of ionic currents and passage of small organic signaling molecules, through electrical synapses (Connors and Long, 2004). The vast majority of these synapses are gap junctions, specialized intercellular contacts with aggregates of transmembrane channels composed of a family of protein subunits termed connexins (Cxs) (Bennett et al., 1991; Dermietzel and Spray, 1993; Bruzzone et al., 1996; Goodenough et al., 1996; Kumar and Gilula, 1996; White and Paul, 1999; Ben-

\footnotetext{
Received April 22, 2004; revised Sept. 24, 2004; accepted Sept. 26, 2004.

This work was supported by the Science Research Promotion Fund from the Promotion and Mutual Aid Corporation for Private Schools of Japan (231016) and by Grants-in-Aid for Scientific Research from the Japanese Ministry of Education, Culture, Sports, Science and Technology to S.H. (03857020, 04857016, and 10680754). Our high-voltage electron microscopic studies were performed in the cooperative program of the National Institute for Physiological Sciences (Okazaki) under 2001-HVEM04, 2002-HVEM05, 2003-HVEM04, and 2004-HVEM02. We are grateful to Drs. Roman R. Poznanski, Masaki Tauchi, and Taei Matsui for reading the first draft of this manuscript and providing helpful suggestions for improvement. We greatly appreciate Drs. Tatsuo Arii and Noboru Yamaguchi for excellent maintenance of the HITACHIH-1250M electron microscope and valuable advice pertaining to ultrastructural studies. We thank Drs. Masamitsu Yamauchi and Toshiaki Katoh for technical advice pertaining to biochemical experiments and Chieko Nishikawa, Tomomi Hanji, Akiko Gotoh, Naomi Yonezu, Naomi Mizukuchi, Daisuke Ishihara, and Toshitsugu Tanaka for technical assistance.

Correspondence should be addressed to Dr. Soh Hidaka, Department of Physiology, Fujita Health University School of Medicine, Toyoake, Aichi 470-1192, Japan. E-mail: shidaka@fujita-hu.ac.jp.

DOI:10.1523/JNEUROSCI.3319-04.2004

Copyright $\odot 2004$ Society for Neuroscience $\quad 0270-6474 / 04 / 2410553-15 \$ 15.00 / 0$
}

nett, 2000). The study of electrical synapses in the CNS needs comprehensive evidence showing functional significance by simultaneous physiological dual recordings between neighboring cells of certain neuronal type and structural identification of gap junctions between the examined cells. Such studies are considered to be less copious and, in fact, might be relatively rare.

In retinal ganglion cells, the major visual excitatory neurons that encode integrated signals from retinal interneurons in spike trains to sense visual information in higher brain centers, the occurrence of electrical synapses between neighboring cells has been proposed by electrophysiological recordings of distributed spike activity (Mastronarde, 1983a,b,c, 1989; Meister et al., 1995; Neuenschwander and Singer, 1996; Brivanlou et al., 1998; DeVries, 1999; Hu and Bloomfield, 2003). For a specific mammalian cell type, Y-type retinal ganglion cells [the physiological correlates of $\alpha$-type ganglion cells ( $\alpha$-GCs)], synchronous spike activity with a short latency has been described in the cell population (Mastronarde, 1983a,b,c, 1989; DeVries, 1999; Hu and Bloomfield, 2003). The presence of electrical synapses between GCs has been supported by cytochemical findings of tracer diffusion after intracellular injection into individual cells (Vaney, 1991, 1994; Dacey and Brace, 1992; Xin and Bloomfield, 1997) and ultrastructural observation of gap junctions in $\alpha$-GCs of the rat (Hidaka and Tauchi, 1993), cat (Kolb and Nelson, 1993) and parasol cells (a homolog of $\alpha$-GC) of the primate (Jacoby et al., 
1996). However, direct evidence that $\alpha$-GCs are connected by dendrodendritic gap junctions is missing.

The recently discovered connexin36 (Cx36) (Condorelli et al., 1998; Söhl et al., 1998), a mammalian homolog of skate and perch Cx35 (O’Brien et al., 1996, 1998; White et al., 1999; Al-Ubaidi et al., 2000), was analyzed exclusively in inhibitory interneurons such as retinal AII (rod) amacrine cells (Feigenspan et al., 2001; Güldenagel et al., 2001; Mills et al., 2001; Deans et al., 2002) and cortical GABAergic interneurons (Deans et al., 2001; Hormuzdi et al., 2001; Amitai et al., 2002; Maier et al., 2002; Buhl et al., 2003). However, we have demonstrated that certain types of GCs express Cx36, supporting our previous findings performed on the AII cells (Hidaka et al., 2002). Our results proved that Cx36 is a molecular marker for gap junctions between $\alpha$-GCs after electrophysiological examination.

In this study, we ultrastructurally demonstrate the occurrence of dendrodendritic electrical synapses between rat $\alpha$-GCs after intracellular Neurobiotin injection and dual patch-clamp recordings from pairs of visually identified $\alpha$-GCs. After intracellular staining of the cell pairs by dual recordings, Cx36 immunoreactivity provides anatomical evidence for the localization of gap junctions in dendrodendritic connections between $\alpha$-GCs.

\section{Materials and Methods}

Animal use. Experiments were performed with 36 Wistar rats (4 weeks to 4 months postnatal) weighing 50-250 gm. Animal use was in accordance with the legislation by the Physiological Society of Japan regulating the use of animals in research and the recommendations of the National Institutes of Health Guide for the Care and Use of Laboratory Animals (National Institutes of Health, Bethesda, MD). Animals were commercially supplied by a breeder (Japan SLC, Hamamatsu, Shizuoka, Japan) and maintained with the light phase from 7:00 A.M. to 7:00 P.M. in an animal room under control of temperature at $23^{\circ} \mathrm{C}$ until use. The animals were deeply anesthetized with an intraperitoneal injection of $5 \%$ sodium pentobarbital ( $0.2 \mathrm{ml}$ injection/100 gm weight) or $50 \%$ urethane $(0.5 \mathrm{ml}$ injection/100 gm weight) and a local injection of $2 \%$ lidocaine hydrochloride to the eyelids and surrounding tissue, before operation for removal of eyeballs from animal bodies.

Intracellular labeling and dye transfer measurement. For measurement of dye transfer between GCs, the eye was removed from animals and hemisected. The retina was isolated from the pigment epithelium, and the vitreous humor was removed. The isolated retina was placed on filter membrane paper (catalog \#AAWG01300; Millipore, Bedford, MA) in photoreceptor cell-side down, using slight suction to make them adhere. The tissue was transferred to Ames' medium (which is buffered with 1.9 $\mathrm{gm} / \mathrm{l}$ sodium bicarbonate and bubbled continuously with a gas mixture of $95 \% \mathrm{O}_{2}$ and $5 \% \mathrm{CO}_{2}$ ), placed in a superfusion chamber with GC-side up, and maintained at $30-35^{\circ} \mathrm{C}$. The perfusion chamber was mounted on the stage of a fixed-stage upright light microscope (E-600FN type; Nikon, Tokyo, Japan), equipped with a patch-slice micro-incubator (Harvard Apparatus, Holliston, MA). The tissue was perfused at $1 \mathrm{ml} / \mathrm{min}$ with filtered Ames' medium and equilibrated with 95\% $\mathrm{O}_{2} / 5 \% \mathrm{CO}_{2}$. The tissue was viewed through a $40 \times / 0.80$ numerical aperture, water immersion, long working-distance objective (Nikon). Cell bodies of $\alpha$-GCs were identified by the size $(>20 \mu \mathrm{m}$ in diameter) and their characteristic nuclei (Tauchi et al., 1992) under Nomarski differential interference illumination.

Intracellular Neurobiotin labeling was obtained from GCs in retinal whole-mounted preparations using either microelectrode manner or whole-cell patch-clamp configurations. For microelectrode labeling of these cells, the visually controlled intracellular injection technique of dyes via glass micropipettes under the fixed-stage microscope was used (Tauchi and Masland, 1984; Tauchi et al., 1992). Micropipettes were pulled from boroscilicate glass capillaries (outer diameter, $1.0 \mathrm{~mm}$; inner diameter, $0.58 \mathrm{~mm}$; Clark Electromedical Instruments, Pangbourne, UK) with a vertical pipette puller (model 700C; David Kopf Instruments, Tujunga, CA), filled at their tips with $6 \%$ Neurobiotin (Vector Labora- tories, Burlingame, CA) and 3\% Lucifer yellow (LY; Aldrich, Milwaukee, WI), dissolved in $0.5 \mathrm{M} \mathrm{LiCl}$ and $0.05 \mathrm{M}$ Tris buffer, $\mathrm{pH}$ 7.6, and then backfilled with $3 \mathrm{~m}$ potassium acetate. LY was used for identification of success of intracellular impalement into neurons by micropipettes. Final DC resistances of these microelectrodes ranged from 350 to $450 \mathrm{M} \Omega$. An individual GC was impaled with an electrode connected with a highimpedance amplifier (MEZ-8301; Nihon Kohdenn, Tokyo, Japan). Neurobiotin and LY were then injected into the cell, by passing polarized currents of $\pm 1 \mathrm{nA}$ (duration of $500 \mathrm{msec}$ ), at $1 \mathrm{~Hz}$ for 2-10 min (Hidaka et al., 1993; Umino et al., 1994; Hidaka and Miyachi, 2003).

Electrophysiological characterization of GCs was performed by single whole-cell recordings using a patch pipette filled with an intracellular solution (see below) involving $0.5 \%$ Neurobiotin and $0.1 \% \mathrm{LY}$. The Neurobiotin-injected retinas were fixed in fixative containing $4 \%$ paraformaldehyde and $0.15 \mathrm{M} \mathrm{NaCl}$ in $0.1 \mathrm{M} \mathrm{PBS}, \mathrm{pH} 7.4$, for $2 \mathrm{hr}$ at room temperature. After fluorescent microscopic confirmation of single-cell LY labeling of individual injected cells to exclude specimens of double (or multiple) microelectrode penetration or LY leakage into neighboring cells under a blue excitation (Nikon), the localization of Neurobiotin was visualized by incubation with a solution of either avidin-biotin- horseradish peroxidase (HRP) complex (ABC; Elite kit; Vector Laboratories) in PBS, pH 7.5, or HRP-streptavidin (Vector Laboratories) in PBS, $\mathrm{pH}$ 7.8 , followed by the reaction with diaminobenzidine (DAB; Dozin, Tokyo, Japan). Tracer coupling and dendrodendritic connections between GCs were microscopically examined and photographed in black and white negative (Kodak T-MAX 400) or color-positive films (Fujichrome PROVIA 400F). Images were taken into a personal computer using Adobe Photoshop application program (Adobe Systems, San Jose, CA), equipped with a $35 \mathrm{~mm}$ film scanner (LS-1000; Nikon). Neurobiotinlabeled specimens were also used for electron microscopic analysis (see below).

Dual patch-clamp recordings. The action potentials and electrical coupling between GCs described below were measured from pairs of cells in retinal flat-mounted preparations. Recordings were made from these cells in situ to identify $\alpha$-GCs by the characteristic morphology of their somata and dendritic extension (Peichl et al., 1987; Peichl, 1989; Tauchi et al., 1992). The somata of GCs were exposed by either mechanical disruption of the surface of the retina using fine forceps operation or enzymatic removal of the Müller glia endfeet and the inner limiting membrane by treating the retina with papain. A modification of the enzymatic processing of the rabbit retina, developed by Velte and Masland (1999), was used for exposition of GC somata in the albino rat retinas. The tissue was incubated in the following activated enzyme solution: $20 \mathrm{U} / \mathrm{ml}$ papain (catalog \#LS003126; Worthington Biochemical, Lakewood, NJ), 1 mM L-cysteine, and 0.5 mM EDTA in Earl's balanced salt solution (BSS) at $37^{\circ} \mathrm{C}$ for $10-30 \mathrm{~min}$. To stop the enzymatic digestion, $10 \mathrm{mg} / \mathrm{ml}$ Ovomucoid and $10 \mathrm{mg} / \mathrm{ml}$ bovine serum albumin (BSA) were applied for $5 \mathrm{~min}$ in Earl's BSS (all from Sigma, St. Louis, MO). After washing, the retina was treated with $0.2 \mathrm{Kunitz} \mathrm{U} / \mathrm{ml}$ DNase I (catalog \#LS002172; Worthington Biochemical) for $10 \mathrm{~min}$ at $37^{\circ} \mathrm{C}$. In the experiments, the extracellular solution bathing the retinas contained (in $\mathrm{mm}$ ) $125 \mathrm{NaCl}, 2.5 \mathrm{KCl}, 2.5 \mathrm{CaCl}_{2}, 1 \mathrm{MgCl}_{2}, 25 \mathrm{NaHCO}_{3}$, and 25 glucose (305-315 mosmol/ $\mathrm{kg}$ ) and was bubbled continuously with $95 \% \mathrm{O}_{2} / 5 \%$ $\mathrm{CO}_{2}$ at $30-35^{\circ} \mathrm{C}$. Chemicals were added to the external solution. The concentration of the chemicals was as follows (in $\mu \mathrm{M})$ : 30 CPP [3-(2carboxypiperazin-4-yl)-propanephosphonic acid], 10 CNQX (6-cyanol7-nitroquinoxaline-2,3-dione), 10 bicuculine, 1 strychnine, $2500 \mathrm{CoCl}_{2}$ (all from Sigma), and 1 tetrodotoxin (TTX; Sankyo, Tokyo, Japan).

Simultaneous dual whole-cell recordings were performed in rupturedpatch mode (Sakmann and Neher, 1995; Hidaka and Ishida, 1998), using dual Axopatch 200B amplifiers (Axon Instruments, Foster city, CA). Pipettes were pulled with the P-97 model pipette puller (Sutter Instruments, Novato, CA) from boroscilicate glass capillaries (outer diameter, $1.5 \mathrm{~mm}$; inner diameter, $0.86 \mathrm{~mm}$; Sutter Instruments) to tip resistances of 3.5-5 M $\Omega$. Pipette (intracellular) solution consisted of (in $\mathrm{mM}$ ) 117 K-gluconate, $13 \mathrm{KCl}, 3.4 \mathrm{NaCl}, 1 \mathrm{CaCl}_{2}, 2 \mathrm{MgCl}_{2}, 10$ BAPTA [1,2-bis(2aminophenoxy)ethane- $N, N, N^{\prime}, N^{\prime}$-tetraacetic acid], 10 HEPES, $5 \mathrm{Mg}$ ATP, and $0.8 \mathrm{Na}_{2} \mathrm{GTP}$. LY was added $(1-5 \mu \mathrm{g} / \mu \mathrm{l})$ to the internal solution $(0.1-0.5 \%)$, and the $\mathrm{pH}$ of this solution was adjusted to 7.3 with potas- 
sium hydroxide solution (total $\mathrm{K}^{+}$concentration was $140 \mathrm{~mm}$ ). Osmolarity was adjusted to $285-295 \mathrm{mosmol} / \mathrm{kg}$ with sucrose.

Closely located large cell bodies of $>20 \mu \mathrm{m}$ in diameter were first approached by dual electrodes under the bright-field illumination. We targeted two larger cell bodies of $\sim 100-200 \mu \mathrm{m}$ apart because they could probably be selected for $\alpha$-GCs of the same morphological type. Then, these cells were sequentially patched using LY-filled pipettes. When individual dendrites of these cells were once filled with the dye under fluorescent observation, the presence of dendritic contacts could be identified. $\alpha$-GCs of the same type expanding their dendrites in the same sublayer of the inner plexiform layer (IPL), i.e., the same physiological type (Famiglietti et al., 1977; Dowling, 1987), were connected with each other at their dendrites (see Results). After we established the whole-cell mode, cells were generally held at a membrane potential of $-60 \mathrm{mV}$. The holding potentials were corrected for liquid junction potentials.

Depolarizing and hyperpolarizing current pulses were applied to one of the potentially coupled $\alpha$-GCs. Voltage responses recorded in currentclamp mode from the other cell indicated electrical coupling between these neurons. The coupling coefficient between two cells was determined as the ratio of the voltage response in cell 2 divided by the voltage response in cell 1 under steady-state conditions. The fast current-clamp feedback circuitry of the Axopatch 200B was used in all current-clamp recordings. Current protocols and off-line analysis were performed with the pClamp 8 and 9 system (Axon Instruments). The voltage monitor output of the patch-clamp amplifier was analog filtered with a Bessel filter that built-in to the Axopatch 200B (corner frequency, $1 \mathrm{kHz}$ ) and digitally sampled at twice the filter frequency (or faster). Series resistance typically measured $<15 \mathrm{M} \Omega$ (range of values measured at the beginning of current measurements from individual cells: 7-14 M $\Omega$ ). Cells with series resistance above $17 \mathrm{M} \Omega$ were excluded from analysis. For examination of synchronous spike firing in the cell pair by dual recordings, time delay between generation of action potentials from the two cells was analyzed with the pClamp 9 system. Cross-correlations were determined from trains of action potentials by computing the temporal interval from the time of the transient peak of each action potential in one cell to the time of occurrence of all action potentials in the other cell. The resolution of the intervals was $0.1 \mathrm{msec}$.

Electron microscopic analysis. According to methods described previously for three-dimensional analysis of dendrodendritic connections between Neurobiotin-labeled neurons by high-voltage electron microscopy (Hidaka et al., 1993; Hidaka and Miyachi, 2003), the DAB visualization was performed by the heavy metal intensification of HRP reaction in the presence of $0.1 \mathrm{M}\left(\mathrm{NH}_{4}\right)_{2} \mathrm{Ni}\left(\mathrm{SO}_{4}\right)_{2}$ and $0.1 \mathrm{M} \mathrm{CoCl}_{2}$, dissolved in $0.1 \mathrm{M}$ Tris buffer, $\mathrm{pH} 7.8$ (Adams, 1981). The reaction products were further processed by the photochromic intensification with $0.02 \%$ nitro blue tetrazolium (Sigma), dissolved in $0.1 \mathrm{M}$ Tris buffer, $\mathrm{pH}$ 8.2, under green excitation of fluorescent microscopy (Vaney, 1992). Before electron microscopic analysis of dendrodendritic connections between the cells, the specimens were examined light-microscopically.

For immuno-electron microscopic analysis of gap junctions involving Cx36, isolated retinas were mounted on Millipore membrane filters in the photoreceptor-side down by slight suction and then fixed in periodate-lysine-paraformaldehyde (PLP) fixative containing $10 \mathrm{~mm}$ sodium- $m$-periodate and $4 \%$ paraformaldehyde in $75 \mathrm{~mm}$ lysine- $\mathrm{HCl}$ and $50 \mathrm{~mm}$ phosphate, $\mathrm{pH}$ 7.4. After PBS wash, retinas were cut into slices in $1 \mathrm{~mm}$ width for electron microscopic analysis. After cryoprotection in PBS containing 20\% sucrose and the freeze-thaw procedure in liquid nitrogen, specimens were incubated with the primary antibody (see below). After PBS washes, the specimens were incubated in secondary antibodies of either goat anti-rabbit IgG $\left[\mathrm{F}\left(\mathrm{ab}^{\prime}\right)_{2}\right]$ conjugated with HRP (Histofine Simple Stain MAX PO-R; Nichirei, Tokyo, Japan) or biotinconjugated goat anti-rabbit IgG [Medical Biological Laboratory (MBL), Nagoya, Japan]. The latter preparation was followed by incubation with the $\mathrm{ABC}$ solution (Vector Laboratories). The immunocytochemical localization was then visualized by the $\mathrm{DAB}$ reaction.

For ultrastructural examination of specimens, tissues were postfixed in $1 \% \mathrm{OsO}_{4}$ in $\mathrm{PBS}$, dehydrated in a series of ethanol-water mixtures, and embedded in a mixture of Epoxy resins involving Glycidether 100 (Serva, Heidelberg, Germany). To enhance electron density of the spec- imens for high-voltage electron microscopic analysis of thick sections, en bloc stainings were made in three steps of $3 \% \mathrm{~K}_{2} \mathrm{Cr}_{2} \mathrm{O}_{7}$ in distilled water, $2 \%$ uranyl acetate in $70 \%$ ethanol, and $20 \%$ phosphotungstic acid in the absolute ethanol. Serial tangential sections (5 $\mu \mathrm{m}$ in thickness) of the cells to be studied were made (Hidaka et al., 1986), and the material was examined in a Hitachi H-1250M high-voltage electron microscope at $1000 \mathrm{kV}$ (National Institute for Physiological Sciences, Okazaki, Japan). For analysis of junctional structures between the interconnected dendrites of GCs, serial ultrathin sections from the specimens were studied in a JEOL 1010, JEOL 1200EX, or Hitachi H-7000 conventional electron microscope at 75 or $80 \mathrm{kV}$ fitted with a goniometer stage.

CX36 cDNA constructs and transfection into cell line. The isolated neural retinas of rats were immediately preserved by freezing with liquid nitrogen. Total RNA from homogenization of the freezed retinas was isolated with the RNeasy Mini kit (Qiagen, Hilden, Germany). Reverse transcription (RT) from poly $\left(\mathrm{A}^{+}\right) \mathrm{RNA}$ to cDNA and amplification of cDNA by PCR were performed with the Ready-To-Go RT-PCR Beads kit according to the manufacturer's protocol (Amersham Biosciences, Buckinghamshire, UK). The transcribed cDNA was amplified by PCR using the following primers that derived from the $\mathrm{Cx} 36$ sequence in the retina and brain of mouse and Sprague Dawley rat (Condorelli et al., 1998; Söhl et al., 1998): forward primer, 5' ${ }^{\prime}$-CACAGCGATGGGGGAATGGA-3'; reverse primer, 5'-TGCCCTTTCACACATAGGCG-3'. PCR was performed for 32 cycles using a GeneAmp 9700 PCR Thermocycler (Perkin Elmer, Foster City, CA) with the following program: denaturing at $94^{\circ} \mathrm{C}$ for $30 \mathrm{sec}$, annealing at $55^{\circ} \mathrm{C}$ for $30 \mathrm{sec}$, elongation at $72^{\circ} \mathrm{C}$ for $1 \mathrm{~min}$. After gel electrophoresis in an agarose gel (1\%), an 980 bp fragment was excised, purified by the gel extraction method of Millipore (Molsheim, France), cloned into the pGEM-T Easy Vector (Promega, Madison, WI), and sequenced with vector-specific and sequence-specific primers in a CEQ 2000 Multi-capillary DNA Analysis System (Beckman, Fullerton, CA). The complete sequence was obtained on both strands.

For analysis of Cx36 mRNA transcript in adult rat retina, the isolation of total RNA and RT-PCR assays were performed with a similar protocol described above using the Cx36 primers. Extracted RNA was treated with DNase I (Boehringer Mannheim, Indianapolis, IN) to eliminate contamination with residual genomic DNA. RT-PCR reactions contained 10-80 $\mathrm{ng} / \mu \mathrm{l}$ RNA and $10 \mathrm{ng}$ of sense and antisense primers, mixed with the beads of the RT-PCR kit in a final volume of $50 \mu$ l. The Cx36 primers produced the $980 \mathrm{bp}$ fragment in PCR. Reaction products were analyzed by electrophoresis on agarose gels.

For gene introduction into cell lines, Cx36 cDNA of the full-length coding region was subcloned into the expression vector pcDNA3 (Invitrogen, San Diego, CA) at the EcoRI-XhoI restriction sites. The resulting expression plamid was called pcD-Cx36. COS 7 cells [obtained from Institute for Fermentation, Osaka animal cell bank (Osaka, Japan) and subcloned by dilution to generate parental cell lines] were maintained under subconfluent conditions at $5 \% \mathrm{CO}_{2}$ in DMEM (Sigma) containing $4.5 \mathrm{gm} / \mathrm{l} \mathrm{D}$-glucose and $10 \%$ heat-inactivated fetal bovine serum at $37^{\circ} \mathrm{C}$. Forty-eight hours before transfection, cells were seeded into fresh $10 \mathrm{~cm}$ Petri dishes at a density of $10^{6} \mathrm{cells} /$ plate. Cells were then transfected with $10 \mu \mathrm{g}$ of plasmid DNA/10 $\mathrm{cm}$ dish using a lipofection reagent (GenePORTER; Gene Therapy Systems, San Diego, CA). After 48 $\mathrm{hr}$, the cells were scraped from the plates and collected by centrifugation at $1250 \times g$ for $3 \mathrm{~min}$ at $4^{\circ} \mathrm{C}$. The cell pellet from each plate underwent lysis by the addition of $600 \mu$ l of lysis buffer (Qiagen) for isolation of RNA or of $250 \mu \mathrm{l}$ of homogenate buffer (50 mM Tris- $\mathrm{HCl}, \mathrm{pH} 7.5$ ) containing protease inhibitors (see below) for Western blotting.

Immunoblotting. Antisera against a synthetic peptide corresponding to the predicted intracellular loop of rat retinal Cx36 protein were raised in rabbits. The antigen peptide ( 22 residues spanning Glu 173 to Gly 194 of Cx36), conjugated to keyhole limpet hemocyanin, was commercially synthesized, injected into rabbits, and subsequent bleeds were performed at the MBL. The crude antisera were subjected to an affinity chromatography. Those methods were described in detail previously (Hidaka et al., 2002).

The brain and eyeballs were removed from three rats. Thirty milligrams of brain samples or two isolated retinas were each homogenized in $250 \mathrm{ml}$ of ice-cold homogenization buffer, $50 \mathrm{~mm}$ Tris-HCl, $\mathrm{pH}$ 7.5, or 1 
mм $\mathrm{NaHCO}_{3}, \mathrm{pH} 8.0$, containing protease inhibitors [5 mM EDTA, $1 \mu \mathrm{g} / \mathrm{ml}$ leupeptin, 1 $\mu \mathrm{g} / \mathrm{ml}$ pepstain $\mathrm{A}$, and $1 \mathrm{~mm}$ phenylmethylsulfonyl fluoride (Sigma)]. The protein concentration of the samples was determined by the Lowry method using BSA (Sigma) as a standard. Aliquots (5-50 $\mu \mathrm{g}$ of protein) of tissue homogenates were prepared for SDS-PAGE by mixing an equal volume of SDS-sample buffer $(20 \%$ glycerol, $4 \%$ SDS, $1.2 \%$ $\beta$-mercaptoethanol, and $0.1 \mathrm{~m}$ Tris- $\mathrm{HCl}, \mathrm{pH}$ 6.8). The samples were then electrophoresed on $10 \%$ running gel. The proteins were electrotransferred onto polyvinylidene fluoride (PVDF) membranes (Millipore), followed by blocking with Tris-buffered saline (TBS; $10 \mathrm{~mm}$ Tris- $\mathrm{HCl}, \mathrm{pH} 7.5,150 \mathrm{~mm} \mathrm{NaCl}$, and $0.05 \%$ Tween 20) containing 10\% skim milk (Wako, Osaka, Japan) and $0.05 \% \mathrm{NaN}_{3}$. The membrane was incubated with anti-Cx36 antibody (diluted 1:1000 in TBS) and incubated with HRP-conjugated anti-rabbit IgG (MBL) and streptavidin-conjugated serum (Bio-Rad, Hercules, CA). Immunoreactivity of proteins on the blotted membrane was detected by the enhanced chemiluminescence method (ECL system; Amersham Buchler, Braunschweig, Germany). In a separate experiment, proteins on a PVDF membrane were stained with Coomassie brilliant blue (Sigma).

Immunocytochemical analysis of connexin expression. pcD-Cx36transfected and unaffected (for control) COS-7 cells on the cultured dishes were fixed with the PLP fixative (see above). Fixed COS-7 cells were incubated in a blocking solution of $3 \%$ normal goat serum to block nonspecific binding. The cells were then incubated with the primary and secondary antibodies (see below).

Fourteen female rats were used for immunocytochemical studies under deep anesthesia with pentobarbital. Different fixation protocols, using aldehyde-based fixative and cooled acetone fixation, were used in examination of Cx36 localization in retinal and brain tissue. For paraformaldehyde-based fixation, animals were perfused quickly through the ascending aorta either with a fixative containing $4 \%$ paraformaldehyde in $0.1 \mathrm{M}$ PBS, pH 7.4, or the PLP fixative. Fixed tissue was washed in PBS and immersed in PBS containing 20\% sucrose for cryoprotection. For aldehyde-free protocols, retinas were rapidly frozen in isopentan and cooled by liquid nitrogen, without processing for aldehyde-based fixation. The tissue was embedded in OCT compound (Miles, Elkhart, IN), sectioned $(10-20 \mu \mathrm{m})$ on a cryostat (Leica, Nussloch, Germany) at $-20^{\circ} \mathrm{C}$, and mounted on gelatin-coated slides. Cryosections were dried at -20 or $-80^{\circ} \mathrm{C}$. Some sections from tissue by rapid freezing were exposed for $10 \mathrm{~min}$ to absolute acetone cooled at $-20^{\circ} \mathrm{C}$. The sections were then incubated with the anti-Cx36 antibody (diluted 1:1000 with PBS). Sections were also examined with monoclonal antiCx26 (diluted 1:2000; Zymed, South San Francisco, CA), anti-Cx32 (diluted 1:2000; Zymed), and anti-Cx43 (diluted 1:1000; Chemicon, Temecula, CA) antibodies. Control cryosections were incubated in rabbit preimmune serum. The specimens were then incubated in goat antirabbit IgG $(\mathrm{H}+\mathrm{L})$, conjugated with Alexa Fluor 546 (absorption, 556 $\mathrm{nm}$; maximum emission, $575 \mathrm{~nm}$; Molecular Probes, Eugene, OR). The Cx36-labeled specimens were examined under an epifluorescence microscope with a green excitation (Nikon) for the Alexa Fluor 546 fluorescent labeling. Fluorescent images were also taken on a confocal microscope (see below).

For double-labeling immunofluorescence of Cx36 on AII amacrine cells, the sections were incubated with monoclonal anti-parvalbumin sera (Chemicon), after the incubation with anti-Cx36 antibody and antirabbit IgG conjugated with Alexa Fluor 546. Subsequently, the specimens were incubated in goat anti-mouse $\operatorname{IgG}(\mathrm{H}+\mathrm{L})$, conjugated with Alexa
Fluor 488 (absorption, 495 nm; maximum emission, 519 nm; Molecular Probes).

For examination of $\mathrm{Cx} 36$ localization in intracellularly labeled neurons, retinas involving LY-filled GCs (see above) were incubated with anti-Cx36 antibody and anti-rabbit IgG conjugated with Alexa Fluor 546. For Cx36 localization probed by Alexa Fluor 546, fluorescent images were taken on a confocal laser-scanning microscope (LSM510; Carl Zeiss, Oberkochen, Germany), using the $543 \mathrm{~nm}$ line of a helium-neon laser under the $560 \mathrm{~nm}$ long-pass filter. For double-labeling immunofluorescence of $\mathrm{Cx} 36$ on identified neurons, images were obtained on the LSM510, using the multiscan function with a combination of the $543 \mathrm{~nm}$ laser under the $560 \mathrm{~nm}$ cut filter for Cx36 and the $458 \mathrm{~nm}$ line of an argon laser under a bandpass filter of $475-545 \mathrm{~nm}$ for LY labeling of GCs, or the $488 \mathrm{~nm}$ laser under a bandpass filter of $500-530 \mathrm{~nm}$ for parvalbumin labeling probed by Alexa Fluor 488. Digital images acquired from the confocal microscope were processed in Abobe Photoshop (Adobe Systems) to adjust brightness and color contrast of the multichannel signals.

\section{Results}

\section{Electrophysiological and morphological properties of $\alpha$-GCs}

Candidates of $\alpha$-GCs were large cells having polygonal or spherical soma larger than $20 \mu \mathrm{m}$ in diameter (Tauchi et al., 1992) in the GC layer (GCL) of the adult [postnatal day 70 (P70)] female Wistar rat. Under the microscopically controlled experiments (see Materials and Methods), the dendritic morphology of Lucifer-injected large cells was characteristic of rat $\alpha$-GCs (Peichl, 1989; Tauchi et al., 1992). We excluded results from $\delta$-type GCs (Peichl, 1989). As shown in Figure 1, all $\alpha$-GCs examined in our patch-clamp studies $(n=56)$ generated sustainedly repetitive spike firing against depolarizing currents (maximum spike frequency, $75 \mathrm{~Hz}$ ). These spikes were completely eliminated in TTX application. To large hyperpolarizing current injection, membrane voltage of the cells was strongly depolarized, sometimes beyond holding potential of $-70 \mathrm{mV}$ after a transient hyperpolarization during injection, and they produced repetitive spikes in the cessation of the current (Fig. 1A). Under perfusion by bath solution including $3 \mathrm{~mm} \mathrm{CsCl}$, the depolarization during injection of hyperpolarizing currents and 
the anode-break spikes disappeared (data not shown). These results suggest that the rat $\alpha$-GCs possessed hyperpolarizationactivated currents $\left(I_{\mathrm{h}}\right)$ that were previously reported in GCs of the goldfish retina (Tabata and Ishida, 1996).

Figure $1 B$ shows extensive Neurobiotin transfer to neighboring $\alpha$-GCs from a recorded cell of an adult rat, after cytochemical detection of localization of the tracer that was intracellularly injected into the cell via a patch pipette. The occurrence of tracer coupling was seen in $\alpha$-GCs of both inner type ( $n=9$ of 33 cells) and outer type ( $n=15$ of 29 cells). $\alpha$-GCs of inner type expanded their dendrites in the proximal part, which are the morphological correspondence to ON-center cells, whereas outer-type cells had the dendrites ramified in the distal layer (the morphological counterpart of OFF-center cells) of the IPL. Tracer coupling was detected between $\alpha$-GCs of the same morphological type (homologous coupling) in the rat retina. These tracer coupling patterns of $\alpha$-GCs resemble distribution of the reduced silverstained cells (Peichl, 1989). $\alpha$-GCs of the same morphological type were distributed in a regular hexagonal array, as reported previously in the cat retina (Wässle et al., 1981). Calculated from the distribution of the tracer-coupled $\alpha$-GCs of inner type in the mid-peripheral region (1-3 mm from the optic disk) of six retinas of female adult rats (P70), the average cell density, nearest neighbor distance, and dendritic field diameter were 19 cells $/ \mathrm{mm}^{2}$, $206 \pm 51 \mu \mathrm{m}$, and $613 \pm 174 \mu \mathrm{m}$, respectively. For outer-type cells in the mid-peripheral region of seven adult retinas, each value was 34 cells $/ \mathrm{mm}^{2}, 117 \pm 31 \mu \mathrm{m}$, and $398 \pm 84 \mu \mathrm{m}$, respectively.

In some cases of Neurobiotin coupling ( $n=5$ of 24 cells), small cells (presumed amacrine cells) having their somata in the inner nuclear layer (INL) were also labeled by single injection into an $\alpha$-GC. We failed to observe any contact between GCs and small cells because dendrites from the small cells were not labeled. Such heterologous coupling was reported in other mammalian retinas (Vaney, 1991, 1994; Dacey and Brace, 1992; Penn et al., 1994; Jacoby et al., 1996; Xin and Bloomfield, 1997). Rat GCs having soma smaller than $18 \mu \mathrm{m}$ in diameter did not show any tracer coupling to neighbors (data not shown) in the present study $(n=31$ cells $)$.

\section{Dendrodendritic gap junctions between $\alpha$-GCs}

Neurobiotin-coupled $\alpha$-GCs of the same morphological type appeared to make contacts with one another. Possible contacts occurred at or near the tips of their peripheral dendrites under light microscopic observation (Fig. $1 B$ ). Neurobiotin could be passed to neighboring $\alpha$-GCs through these intercellular contacts. We investigated by electron microscopy whether gap junctions are really localized at the presumptive contact sites. First, for highvoltage electron microscopy of thick sections in production of a three-dimensional view of the contacts (Hidaka et al., 1986, 1993; Hidaka and Miyachi, 2003), we prepared a series of 5- $\mu$ m-thick sections cut tangentially to the retina. Contacting dendrites from two $\alpha$-GCs were located within a single section where direct dendrodendritic contacts occurred between the labeled cells (Fig. $2 A, B$, arrows). In the contact sites, the two labeled dendrites were tightly apposed with a gap between them. Second, to reveal specialized ultrastructures in the direct contact sites, we prepared serial ultrathin sections from Neurobiotin-labeled retinas. In ultrastructural thin-sectioning examination of the contact sites, labeled dendrites made direct contact with other labeled dendrites where gap junctions could be identified clearly (Fig. 2C). The outer leaflets of plasma membranes of the two contacting dendrites were closely apposed, with a narrow gap of $2.7 \mathrm{~nm}$ width between them, although in these labeled specimens the gap was usually occluded with dense materials, possibly the DAB reaction products. We evaluated the incidence of gap junctions between Neurobiotin-labeled $\alpha$-GC dendrites by quantitatively observing all of the contact sites located in a set of 100 consecutive ultrathin sections. All five contact sites between labeled dendrites of $\alpha$-GCs could be identified convincingly as gap junctions, where no contact site formed conventional chemical synapse. These results suggest that gap junctions appear to be formed between directly contacting $\alpha$-GCs of the same type (homologous gap junctions), but not as mixed synapses. Accordingly, the contact sites with a tightly apposed gap between Neurobiotin-labeled dendrites appear to show gap junctions between coupled $\alpha$-GCs. Third, we estimated the size of gap junction plaques localized between labeled $\alpha$-GC dendrites in the three-dimensional view of 5 - $\mu \mathrm{m}$ thick sections by high-voltage electron microscopy (Fig. $2 A, B$ ) to be $0.86 \pm 0.59 \mu \mathrm{m}(n=14$; ranging from 0.2 to $2.33 \mu \mathrm{m})$ in the longest diameter.

Small gap junctions with the size of $<0.4 \mu \mathrm{m}$ in the longest diameter (Kolb, 1979; Dowling, 1987; Hidaka et al., 1989; Freed et al., 1996; Jacoby et al., 1996) were encountered repeatedly between one labeled and the other Neurobiotin-negative dendrite by ultrastructural thin-sectioning studies (data not shown). These unlabeled processes might be involved in dendrites from the small amacrine cells heterologously coupled to $\alpha$-GCs.

\section{Electrical synapses between $\alpha$-GCs}

Next, we examined whether $\alpha$-GCs of the same morphological type form reciprocal electrical synapses by simultaneous dual whole-cell recordings performed in pairs of these cells. Our Neurobiotin injection into rat $\alpha$-GCs revealed a complete dendritic morphology of the individual cells and somata position of coupled cell population of the same type (Fig. 1). Inner-type cells could be identified with their extra large $(>28 \mu \mathrm{m}$ in diameter $)$ polygonal somata, whereas the outer type was possible to be discriminated with their large $(>20 \mu \mathrm{m}$ in diameter) but oval or more spherical somata. According to the distribution of somata having these morphological characteristics, neighboring $\alpha$-GCs of the same morphological type were targeted for dual recordings under Nomarski images of rat retinas. Cells were labeled with LY in ruptured whole-cell mode, and their complete dendritic morphology was visualized at the end of the recording. Based on the dendritic stratification in the IPL (Peichl, 1989; Tauchi et al., 1992), the morphological type (e.g., inner or outer type) of our examined $\alpha$-GCs was determined. After establishing the wholecell configuration in a pair of $\alpha$-GCs, we first tested for electrical coupling by applying current commands to one cell and recording the voltage responses in both cells. To isolate the effects of electrical synapses from chemical synaptic transmission, experiments were performed in the presence of antagonists of chemical neurotransmitters (see Materials and Methods). Figure 3 shows whole-cell LY labeling of a pair of outer-type $\alpha$-GCs and electrical coupling between them revealed by simultaneous recordings. Although each outer cell evoked repetitive spikes (Fig. 3A1,A2), voltage responses were recorded in current clamp under application of TTX and $\mathrm{CoCl}_{2}$ to measure steady-state coupling between the cells. Application of a depolarizing current step in one cell generated a large depolarizing voltage change in the injected cell and a voltage response of the same polarity in the other cell. When cells were electrically coupled, a hyperpolarizing current in one cell produced hyperpolarizing voltage responses in both cells (Fig. $3 B, C$ ).

A total of $17 \alpha$-GC pairs showed electrical coupling. For all cell 

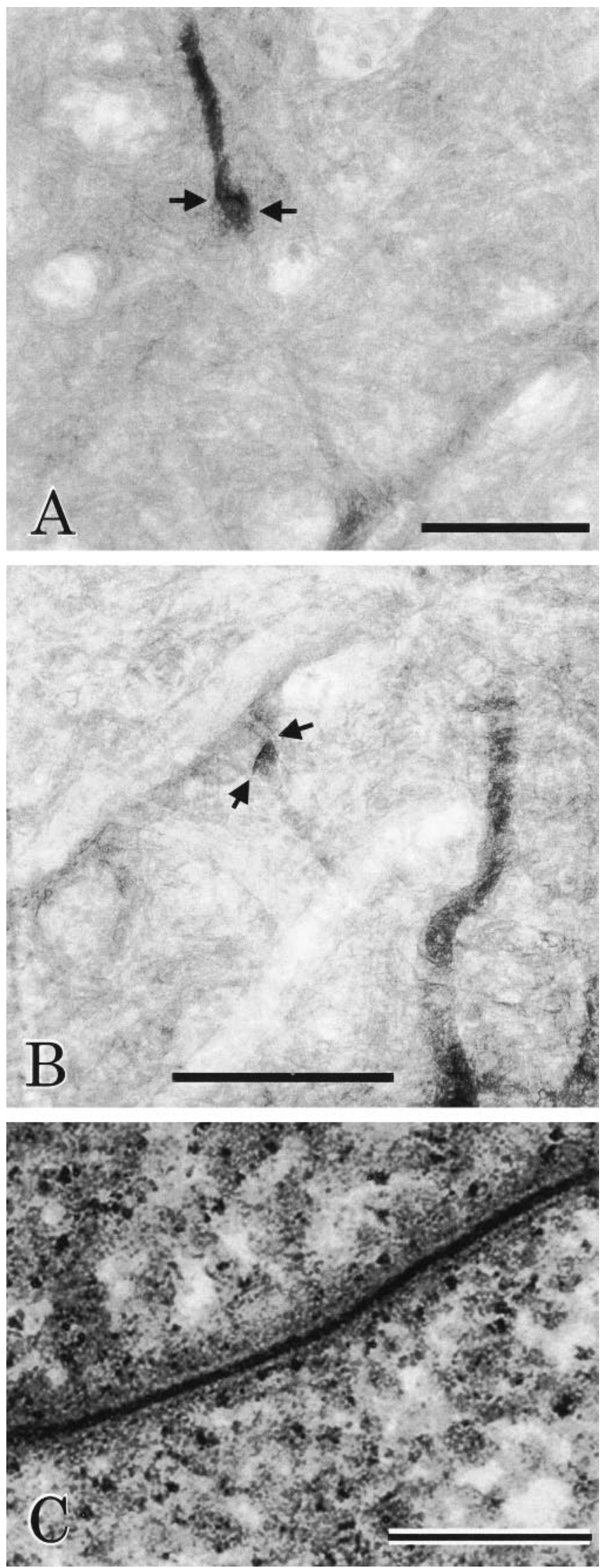

Figure 2. Electron micrographs showing the dendrodendritic gap junctions between Neurobiotin-coupled neighboring $\alpha-\mathrm{GCS}$, revealed by high-voltage $(A, B)$ and conventional ( $C$ ) electron microscopy. $A$, The direct junctional contact (arrows) occurs between the tips of peripheral dendrites from coupled inner-type $\alpha$-GCS. The specimen was observed at $1000 \mathrm{kV}$ in a tangential 5 - $\mu \mathrm{m}$-thick section. $B$, Labeled dendrites make another direct contact with each pairs, the electrical coupling was reciprocal (Fig. $3 B, C$ ). A coupling coefficient was estimated as the ratio of the voltage change in the noninjected cell to that in the injected cell with both cells in current clamp. Steady-state coupling coefficient in an outer cell pair of Figure 3 was 0.32 . The mean steady-state coupling coefficient was $0.13 \pm 0.10(n=17$ cell pairs; range, $0.01-0.32)$. For each cell pair, the coupling coefficient was estimated for both directions of coupling, and the population average was calculated from the average for each pair. The scattered plot shown in Figure $3 D$ indicates that the coupling coefficient was moderately asymmetric when the two directions of coupling were compared. The asymmetric coupling coefficient appeared to be raised by a difference in membrane input resistance between the two coupled cells (Nolan et al., 1999; Veruki and Hartveit, 2002a,b) but not by rectification through gap junctions between the cells. This is because gap junction conductance will be symmetrical between the two directions of coupling (see below). We did not observe any difference in coupling coefficient of inner-cell versus outer-cell pairs.

Next, we measured electrical junction conductance $\left(G_{\mathrm{j}}\right)$ between two coupled $\alpha$-GCs. The junction conductance was estimated with both cells in voltage clamp by applying a series of test voltages to the presynaptic cell and recording the generated currents in both the presynaptic and the postsynaptic cell (Fig. 4). The relationship between junction voltage $\left(V_{\mathrm{j}}\right)$ and junction current $\left(I_{\mathrm{j}}\right)$ was linear (Fig. $4 B$ ) when corrected for nonzero series resistance and finite membrane input resistance. This result indicates that $G_{j}$ was independent of $V_{j}$ over the range of test voltages $( \pm 30 \mathrm{mV})$, even if the poor ability of space clamping is possible in whole-cell recording of $\alpha$-GCs. The junctional conductance was then measured as the slope of a straight line fitted to the $I-V$ relationship $(1.17 \mathrm{nS}$ ) (Fig. $4 B$ ). When the conductance for a cell pair was calculated as the slope conductance determined from each direction of coupling and plotted for both directions of coupling for each cell pair, $G_{j}$ was very similar between them (Fig. $4 C$ ). This result shows that the electrical junction conductance of $\alpha$-GCs was symmetric without rectification. The mean $G_{j}$ was $1.35 \pm 0.51 \mathrm{nS}(n=9$ cell pairs; range, $0.40-2.45 \mathrm{nS})$.

We also recorded from cell pairs $(n=6)$ in which each $\alpha$-GC belonged to different subclass (e.g., between inner and outer type), which was identified by differential dendritic stratification in the IPL of LY-filled cells at the end of the recording. Electrical coupling was not found between such cell pairs, because no contacts between these LY-filled cells were observed under fluorescent microscopic observation. We confirmed the absence of dendritic contacts in the IPL between those cells by laser-scanning confocal microscopy (see below). These results suggest that the observed electrical coupling is attributable to flow of current through dendrodendritic gap junctional connections between $\alpha$-GCs.

One result of electrical synapses between neurons is generation of synchronous spiking (Llinas et al., 1974; Galarreta and Hestrin, 1999, 2001; Gibson et al., 1999; Mann-Metzer and Yarom, 1999; Amitai et al., 2002; Long et al., 2002; Veruki and Hartveit, 2002a; Connors and Long, 2004). The maximum frequencies of spike firing of $\alpha$-GCs in response to depolarizing current injection varied between 16 and $75 \mathrm{~Hz}$. In dual recordings

other at dendritic tips in a tip-to-shank manner. Note the close apposition of the labeled dendrites of the two contacting cells as demarcated by arrows. C, High-magnification view of a gap junction formed between two labeled peripheral dendrites from coupled cells by conventional electron microscopy of an ultrathin section at $75 \mathrm{kV}$. Plasma membranes of the two labeled dendrites are closely apposed with a narrow central gap, $2.7 \mathrm{~nm}$ wide, between the outer leaflets of the apposed unit membranes. Scale bars: $A, B, 10 \mu \mathrm{m} ; C, 200 \mathrm{~nm}$. 


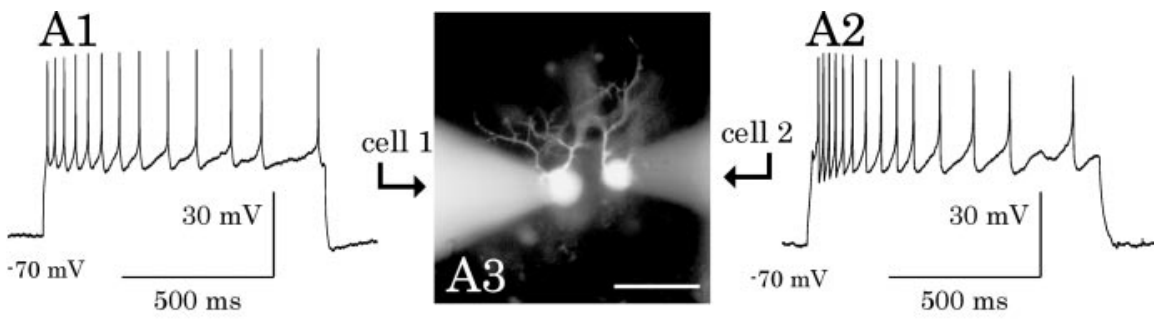

B
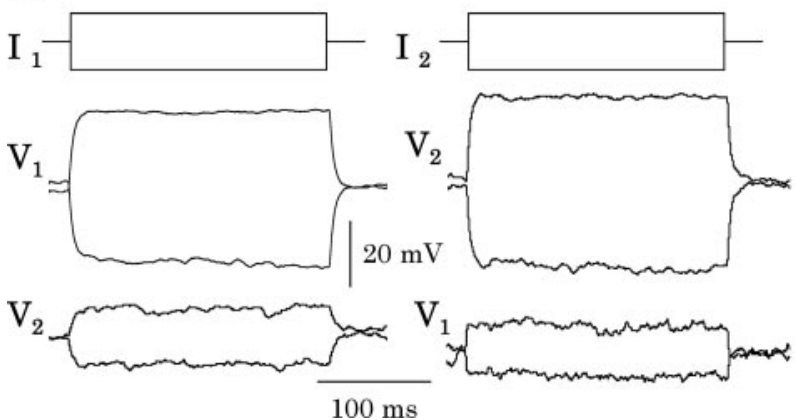

D

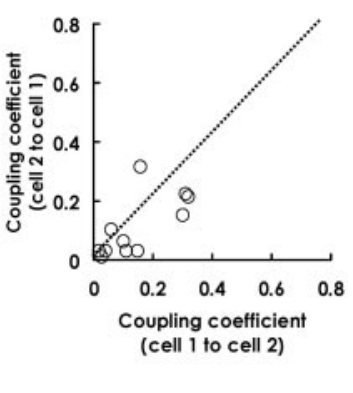

Figure 3. Bidirectional electrical synapses between $\alpha-\mathrm{GCs}$ of the same type, revealed by simultaneous dual patch-clamp recordings. $A 1, A 2$, Spikes of two cells (cells 1 and 2 ) elicited by depolarizing constant-current injection through recording pipettes from a holding potential of $-70 \mathrm{mV}$. $A 3$, Fluorescence photomicrograph of the pair of outer-type $\alpha$-GCs in a whole-mount preparation after filling with LY. Scale bar, $100 \mu \mathrm{m}$. B, With the pair of two neighboring cells in current-clamp condition under dual recordings, 200 msec current pulses $\left(I_{1}\right)$ of -50 and $+50 \mathrm{pA}$ are applied to cell 1 while voltage responses are recorded from both cells $\left(V_{1}\right.$ and $\left.V_{2}\right)$ in the presence of pharmacological blockers of chemical synaptic transmission (see Results). Injection of negative current results in hyperpolarization of both cells, and injection of positive current results in depolarization of both cells. C, Same as in $B$, but the current pulses are applied to cell 2. D, Summary of coupling coefficient between $\alpha$ - $\mathrm{GCS}$. Comparison of coupling coefficient in each direction shows apparent rectification for some cell pairs, when electrical transmission in the same cell pair was examined in both directions (e.g., cell 1 is first presynaptic, and cell 2 is then presynaptic). The dashed line indicates the values expected when the coupling coefficient is the same in both directions for pairs of $\alpha$ - $\mathrm{GCs}$. from pairs of $\alpha$-GCs by simultaneous current clamp, synchronization of spike firing could be identified (Fig. 5, asterisks). In those cell pairs (both inner and outer pairs), the average time delay of the spike peak was $2.7 \pm 2.5 \mathrm{msec}$ (range, 0.5-9.5 msec; $n=18$ cell pairs). Because synchronous firing may be produced by conventional chemical synaptic inputs, we recorded from cell pairs after blocking chemical synaptic transmission pharmacologically (see Materials and Methods). The timing (average time delay, $2.6 \pm 1.8$ msec; range, $0.5-6.5 \mathrm{msec} ; n=13$ cell pairs) of the spike firing of these cells were not distinguishable from those recorded in control solution. In electrically coupled cell pairs under blocking chemical synaptic transmission, we observed that action potentials in one cell produced transient depolarizations in the other cell (Fig. 5A, arrows). This observation suggests that action potentials, from the initiation site close to the soma of one cell, could be propagated along the dendrites of the cell and transmitted up to the dendrites of the neighboring cell through electrical synapses. Then the depolarizing transients would arrive at the recorded site of soma of the other cell. The spiking depolarizations in the cell appeared to cause electrical postsynaptic potentials in the neighboring cell through the electrical synapses (Fig. 5C,D, arrow). Subthreshold membrane potential inputs on generation of
A

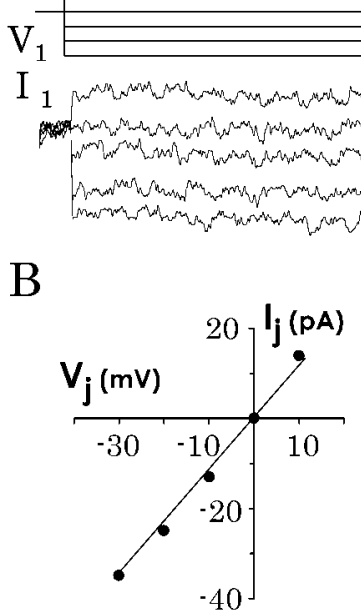
$\mathrm{V}_{2}$

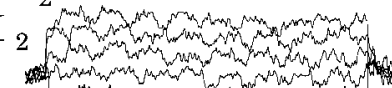

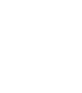

$\mathrm{C}$

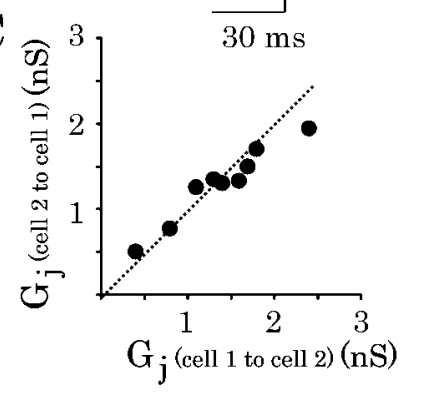

Figure 4. Measurement of electrical junction conductance $\left(G_{\mathrm{j}}\right)$ between $\alpha-\mathrm{GC}$. $A$, With both cells in whole-cell voltage clamp $\left(V_{1}\right.$ and $\left.V_{2}\right)$, voltage steps $(-90$ to $-50 \mathrm{mV}, 10 \mathrm{mV}$ increments) from a holding potential of $-60 \mathrm{mV}$ were applied to one cell $\left(V_{1}\right)$, and current responses were recorded in both cells $\left(I_{1}\right.$ and $\left.I_{2}\right)$. $B$, Current-voltage relationship between the junctional current $\left(I_{\mathrm{j}}\right)$ and the junctional voltage $\left(V_{\mathrm{j}}\right)$ shown in $A$. The plotted data are fit with a straight line, the slope of which shows $G_{\mathrm{j}}$. $C$, Summary of $G_{\mathrm{j}}$. Comparison of $G_{\mathrm{j}}$ in each direction shows nonrectifing electrical synapses, when electrical coupling in the same cell pair was examined in both directions [e.g., $G_{\mathrm{j}}$ (cell 1 to cell 2) for cell 1 presynaptic, and $G_{\mathrm{j}}$ (cell 2 to cell 1 ) for cell 2 presynaptic]. The dashed line indicates the values expected when $G_{j}$ is the same in both directions for pairs of $\alpha$-GCs. the two initial action potentials (Fig. $5 A, B$ ) would be synchronized in response to simultaneous current injections into the two cells, because these spikes were synchronously fired within the time delay of $0.5 \mathrm{msec}$. By formation of EPSPs between a pair of $\alpha$-GCs of the same type, these two cells could generate temporally precise spikes (cf. Veruki and Hartveit, 2002a).

\section{Expression of rat $\mathrm{Cx} 36 \mathrm{mRNA}$ in the retina}

To investigate $\mathrm{Cx}$ types involved in gap junctions between $\alpha$-GCs, $\mathrm{Cx}$ immunoreactivity using antibodies against $\mathrm{Cx} 26, \mathrm{Cx} 32$, or $\mathrm{Cx} 43$ was examined to localize the cells. We did not find any immunocytochemical localization in any plexiform layer localizing retinal neurons, although $\mathrm{Cx} 43$ immunoreactivity was localized in the pigment epithelium layer and inner limiting membrane (data not shown). Cx43 immunoreactivity in the inner limiting membrane was colocalized with a glial fibrillary acidic protein-positive astrocyte (Johansson et al., 1999; Güldenagel et al., 2000; Zahs et al., 2003), apart from the GCL (data not shown). Recently identified neuronal Cx36 (Condorelli et al., 1998; Söhl et al., 1998) is a candidate localized in those gap junctions (Hidaka et al., 2002). First, Cx36 transcript was examined with RT-PCR analysis of total RNA with the Cx36-specific primers (Condorelli et al., 1998; Söhl et al., 1998; Hidaka et al., 2002) in retinas of mature and developing Wistar rats. To clone the full length of rat Cx36 cDNA, total RNA was extracted from isolated neural retinas of adult (6 months of age) and developing (prenatal and P0-P21) animals, retrotranscribed in cDNA and amplified by PCR using the regenerated primers. RT-PCR yielded abun- 


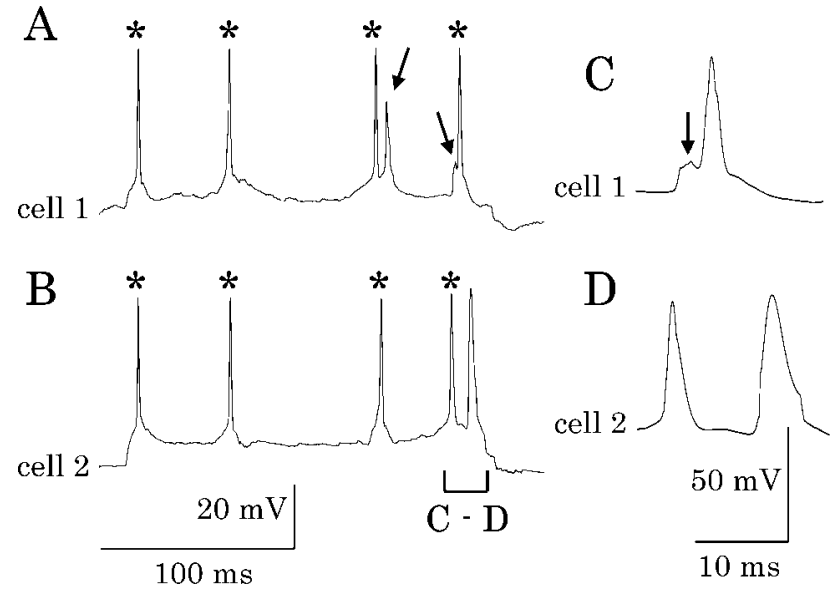

Figure 5. Synchronized spiking in $\alpha$ - $\mathrm{GCs}$ of the same type. $A, B$, Simultaneous membrane voltage responses were recorded from a pair of inner-type $\alpha$-GCs under simultaneous application of depolarizing current injection through dual recording pipettes, after blocking chemical synaptic transmission pharmacologically (see Materials and Methods). The two simultaneously recorded cells ( $A$, cell $1 ; B$, cell 2 ) generated synchronization of spikes (asterisks) within a time delay of $4.4 \mathrm{msec}$. Action potentials in one cell produced transient depolarizations in the other cell (arrows). These cases would be when spikes in one cell were raised with a time delay of over 1.5 msec after generation of spikes in the other cell. C, D, Membrane voltage responses of the two cells in more detail.

dant amplicons corresponding to the length of the $980 \mathrm{bp}$, the expected sizes of $\mathrm{Cx} 36 \mathrm{cDNA}$, from retinas of adult animals and at different postnatal stages of development (data not shown). Second, the corresponding cDNA fragment was cloned and sequenced on both strands. The resulting 980 bp sequence [GenBank/European Molecular Biology Laboratory (EMBL) accession number AJ296282) shows this to be similar as the Cx36 cloned from rat brain (Söhl et al., 1998), which encoded a protein of 321 amino acids with a predicted molecular mass of 36,020 Da. Cx36 was expressed at P0 but not detected at prenatal day 21 . Cx36 expression increased to reach adult level at approximately $\mathrm{P} 10$ and is maintained throughout adulthood.

\section{Functional expression of $\mathrm{Cx} 36$ channels in transfected COS-7 cells}

To identify $\mathrm{Cx} 36$ channel protein and its cellular localization in rat $\alpha$-GCs, we raised a polyclonal antibody against a synthetic peptide corresponding to the intracellular loop of the Wistar rat retinal Cx36 protein (Hidaka et al., 2002). To characterize our generated antibody against $\mathrm{Cx} 36$ and functional expression of Cx36-intercellular channels, green monkey kidney cell line COS-7 cells were transfected with pcD-Cx36. The affinitypurified antisera were used to precipitate lysates from COS-7 wild-type or pcD-Cx36-transfected cells. The anti-Cx36 antisera labeled a protein with an apparent molecular mass of $36 \mathrm{kDa}$, which corresponds to the predicted molecular weight of the rat Cx36 protein. In Western blotting, an immunopositive band migrating at $36 \mathrm{kDa}$ was detected in the transfected cells (Fig. $6 \mathrm{~A}$, lane 2), whereas in COS-7 wild type the $36 \mathrm{kDa}$ band was not seen (lane 1).pcD-Cx36-transfected clones were characterized by immunofluorescence examination and yielded a prominent punctate immunolabeling pattern of connexin-expressing cultured cells on contacting membrane (Fig. 6C), whereas COS-7 wild type showed no immunoreactivity (Fig. 6B). Some transfected clones showed cytoplasmic vesicular Cx36 immunoreactivity (Fig. 6C).

The occurrence of functional intercellular channels in $\mathrm{pcD}-$

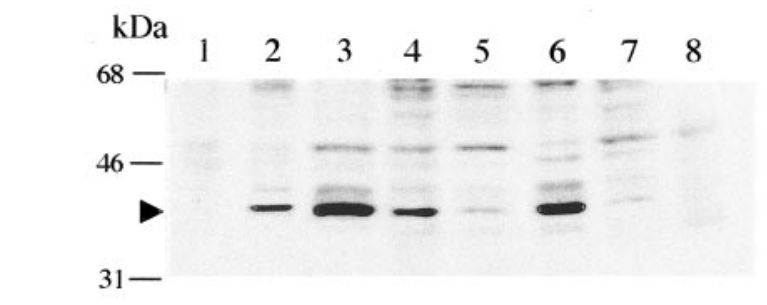

A

COS, COS, Rt, OB, Hipp, CC, CC, Heart Cont pcD Ad Ad Ad P0 Ad
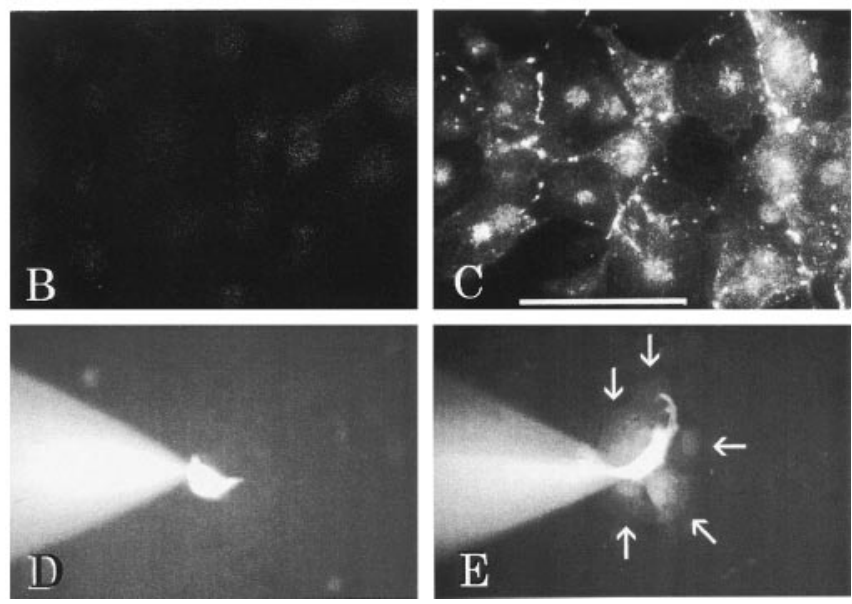

Figure 6. Expression and localization of gap junction channel $\mathrm{Cx} 36$ in COS-7 cells and neuronal tissue. Antisera recognizing $\mathrm{C} \times 36$ channels was raised, using the predicted sequence of rat retinal $\mathrm{X} 36$ protein, the nucleotide sequence of which is available from GenBank/EMBL under accession number AJ296282. A, Western blot analysis of proteins from COS-7 cells and rat tissue homogenates $(10 \mu \mathrm{g})$, probed with affinity-purified anti-Cx36 antisera (see Results). The profiles show a single immunoreactive band with an apparent molecular mass of $36 \mathrm{kDa}$ (arrowhead) in pcD-CX36-transfected COS-7 cells (COS, pCD; lane 2), whereas in COS-7 wild type the band was not seen (COS, Cont; lane 1). A single $36 \mathrm{kDa}$ band was seen in adult rat retina (Rt, $\mathrm{Ad}$; lane 3), olfactory bulb (OB, Ad; lane 4), and PO developing cerebral neocortex (CC, PO; lane 6). A faint signal was detected in the hippocampus (Hipp, Ad; lane 5) and the neocortex (CC, Ad; lane 7) of adult animals. No labeling in the heart (lane 8) was seen. The molecular mass is indicated on the left. $B, C$, Punctate immunofluorescence pattern of $C \times 36$ expression on contacting membrane between cultured $\mathrm{pCD}-\mathrm{C} \times 36$-transfected clones, stained by anti- $\mathrm{C} \times 36$ antisera $(C)$, whereas no immunoreactivity in COS-7 wild type $(B)$ is shown. $D, E$, The formation of functional intercellular channels in $\mathrm{PCD}$-CX36-transfected COS-7 cells, revealed with intracellular injection of $L Y$. The dye diffused into five neighboring cells (arrows) from the injected cell among $\mathrm{pCD}-\mathrm{C} \times 36$ transfected clones $(E)$, whereas no dye coupling in wild type (D) was shown. Scale bar: (in C) $50 \mu \mathrm{m}$.

Cx36-transfected COS-7 cells was investigated with intracellular injection of the fluorescent dye LY (molecular weight, $457 \mathrm{Da}$ ), because gap junctions are permeable to small molecules with $<1$ $\mathrm{kDa}$. Figure $6 E$ shows LY diffusion into neighboring cells from the injected COS-7 among pcD-Cx36-transfected clones $(n=11$ of 19), whereas no dye coupling was seen in COS-7 wild type $(n=$ 0 of 20) (Fig. 6D).

\section{Detection of $\mathrm{Cx} 36$ protein by immunoblotting}

Immunoblotting analysis using our anti-Cx36 antisera demonstrated that a single protein band with an apparent molecular mass of $36 \mathrm{kDa}$ was strongly labeled in lysates from adult rat isolated retina (Fig. 6A, lane 3), adult olfactory bulb (lane 4), and P0 developing cerebral neocortex (lane 6). A faint immunoreactive signal of the $36 \mathrm{kDa}$ protein was seen in the hippocampus (lane 5) and the superficial layers (cerebral white matter) of the neocortex (lane 7) of adult animals, when obtained in the experimental condition similar to that of developing brain. No labeling 


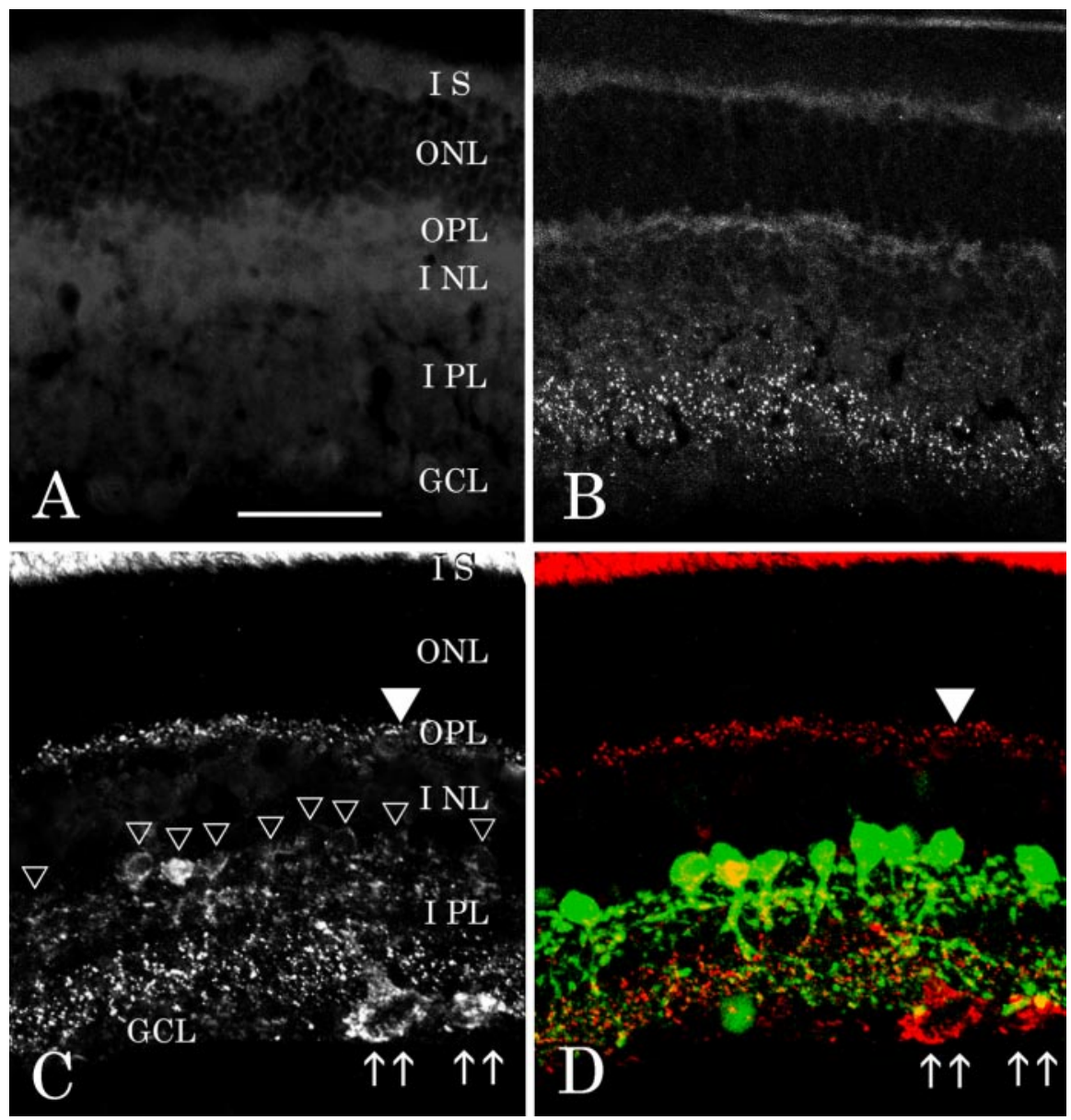

Figure 7. Confocal optical images of immunofluorescent labeling of rat retina with anti-Cx36 antisera. $A$, Control section. $B$, Acetone exposure. A retinal section incubated with anti-Cx36 antibody shows punctate immunofluorescence throughout the IPL. Any intracellular labeling is not observed throughout the retina. Note the absence of puncta in the OPL. C, Paraformaldehydebased fixation. Discrete punctate signals are seen throughout the OPL (filled arrowhead) as well as the IPL, and cytoplasmic immunolabeling of somata (open arrowheads) in the conventional amacrine cell layer and the GCL (large perikarya; indicated by double arrows) is shown. The puncta of the IPL are equivalent between paraformaldehyde-fixed and acetone-exposed retinas $(B)$. In the $O P L$, relatively large and brilliant puncta are visible. $D$, The immunoreactivity against $C \times 36$ (red) and parvalbumin (green) was merged in a single image by double labeling of the same section as C. Perikaryal immunoreactivity (indicated by open arrowheads in $C$ demonstrates colocalization with the diffuse parvalbumin immunolabeling (yellow). IS, Inner segments of photoreceptor cells; 0NL, outer nuclear layer. Scale bar: (in A) $50 \mu \mathrm{m}$.

was present in the heart (lane 8) and liver (data not shown). Our studies indicated a high level of expression of $\mathrm{Cx} 36$ protein in the retina and olfactory bulb, but a much lower level in the neocortex of adult rats. From these immunoblotting results, compatible with previous reports using alternative anti-Cx36 antibodies (Belluardo et al., 2000; Rash et al., 2000; Teubner et al., 2000), the specificity of our antisera against $\mathrm{Cx} 36$ protein could be shown.

\section{Expression of Cx36 in retinal amacrine and GCs}

Immunocytochemical labeling of rat retinas, using the anti-Cx36 antibody, demonstrated discrete punctate immunosignals of subcellular structures likely to be associated with gap junctions (see below) and cytoplasmic vesicular immunoreactivity of somata and dendrites (Fig. 7). Control cryosections in which the primary antibody was replaced by rabbit preimmune serum showed no immunolabeling in the retina, although autofluorescence of the inner and outer segments of photoreceptor cells was present (Fig. 7A). In retinas treated with acetone after rapid freezing, brilliant immunopuncta were clearly visible throughout the IPL (Fig. $7 B$ ). In retinas fixed with paraformaldehyde-based fix- ative, fluorescent punctate labeling was detected both in the outer plexiform layer (OPL) and IPL (Fig. 7C). The Cx36 immunosignals in the IPL were particularly bright at sublayers 3,4 , and 5 and rather lightly distributed at layers 1 and 2 . In aldehyde-fixed retinas, the punctate fluorescence of the OPL was larger and more brilliant than that of the IPL (Fig. $7 C$, arrowhead). In the OPL of acetone-exposed retinas, fluorescent puncta were mostly decreased (Fig. $7 B$ ), but in the IPL, puncta similar to that of aldehyde-fixed retinas were visible. These results demonstrate that the OPL punctate fluorescence detected in aldehyde-fixed retinas but not for acetone-exposed preparations may not be associated with membrane channels close to gap junctions, because ethanol and acetone fix proteins bound to cytoskeletons and membranes but easily dialyze neutral lipid and soluble proteins from tissue in cytochemical processing.

There was some prominent cytoplasmic $\mathrm{Cx} 36$ immunoreactivity of somata in the inner row of the INL and in the GCL, and immunolabeling of dendritic processes within the IPL, but nuclei were free of label (Fig. 7C). The cytoplasmic labeling in these retinal neurons is likely associated with abundant synthesis of high concentrations of $\mathrm{Cx} 36$ protein. The perikaryal immunolabeling in the INL appears to be from amacrine cells, proving that these cells synthesize high concentrations of $\mathrm{Cx} 36$ protein and form gap junctions involving $\mathrm{Cx} 36$ in their dendrites. Recent double-immunostaining experiments (Feigenspan et al., 2001; Mills et al. 2001) using other Cx36 antibodies and a neuronal marker of AII amacrine cells, anti-parvalbumin sera for rat retina (Wässle et al., 1993), or anti-calretinin antibody for rabbit retina (Massey and Mills, 1999) have reported that Cx36 immunopuncta were overlapped on dendrodendritic contacts between the cells. However, their alternative immunocytochemical method with those antibodies failed to label cytoplasmic $\mathrm{Cx} 36$ protein in the AII cell somata. To address cytoplasmic localization of $\mathrm{Cx} 36$ protein in the AII somata, the Cx36 antibody was used with double-labeling fluorescence using antiparvalbumin sera in the rat retina by the multiscan function equipped in confocal laser-scanning microscopy (see Materials and Methods). Figure $7 D$ illustrates immunolabeling against parvalbumin of amacrine cells (green), merged with Cx36 immunoreactivity (red) shown in Figure 7C. All parvalbuminimmunopositive somata involving yellow vesicles in the INL indicated Cx36 cytoplasmic immunoreactivity (Fig. 7C, open arrowheads). Some of the AII cells showed prominent Cx36 cytoplasmic immunolabeling.

A vesicular pattern of cytoplasmic immunofluorescence was frequently observed in large perikarya of the GCL (Fig. 7C, double arrows). Laser-scanning microscopy demonstrated that localization of cytoplasmic immunofluorescence was restricted in the 
perinuclear region of GC somata larger than $20 \mu \mathrm{m}$ in diameter (Fig. 8A,B). The fluorescent intensity, indicated as red vesicles in Figure $8 B$, was closely associated with the extent of formation of vesicular structures (Fig. 8A, arrows). Preembedding immunoelectron microscopy confirmed the Cx36 localization in perikaryal vesicular structures of large GCs (Fig. 8C). These results suggest that synthesis of high concentrations of protein may lead to focal accumulations in the subcellular compartments of large GC perikarya. The Cx36-immunopositive large cells in the GCL appear to be somata of $\alpha$-GCs.

Our immunoelectron microscopy has revealed that localization of $\mathrm{Cx} 36$ puncta in the IPL reflect the presence of gap junction plaques there. In high-voltage electron microscopy of thick tangential sections through the IPL, numerous punctate Cx36 immunolocalization was distributed in the IPL, where junctional structures labeled by reaction product were seen (Fig. $8 D$, arrows). In thin-sectioning immunoelectron microscopy of these puncta, Cx36 immunoreactivity in the IPL was restricted to gap junction plaques (Fig. $8 E$ ). The Cx36 puncta in the IPL may also be involved in possible gap junctions between $\alpha$-GCs. However, we never found any junctional structures with close membrane apposition in the OPL puncta by electron microscopy (data not shown). This ultrastructural result indicates that the brilliant OPL puncta by fluorescent microscopy (Fig. 7C,D, filled arrowheads) may not reflect possible localization of any gap junctions between distal retinal neurons. This contrasts with a recent description of Cx36 localization in possible gap junctions between photoreceptors using alternative antibodies against $\mathrm{Cx} 36$, immunocytochemical methods (Lee et al., 2003), and in cones and bipolar cells of transgenic mice with $\mathrm{Cx} 36$ attaching green fluorescent protein (Feigenspan et al., 2004). It remains to be determined whether fine ultrastructures of gap junctions are present in the OPL puncta associated with distal neurons. The majority of the brilliant OPL puncta might reflect the cytoplasmic localization associated with possible membrane channels in the dendritic or axonal processes from distal neurons.

To provide direct evidence of Cx36 expression in $\alpha$-GCs, intracellular LY filling of $\alpha$-GCs was documented with Cx36 immunolabeling. The multiscan function in the confocal microscopy (see Material and Methods) was used in Cx36 immunolabeling on the LY-labeled retinas. Figure 9 demonstrates projected images from confocal optical sections, consisting of LY labeling (green) of an inner-type $\alpha$-GC showing somatic Cx36 immunoreactivity (Fig. 9C) and punctate immunolabeling distributed in the IPL (Fig. 9D, red vesicles). In Figure 9A, the dendritic expansion illustrated a typical cellular morphology of rat inner-type $\alpha$-GCs (Peichl, 1989; Tauchi et al., 1992). Some peripheral dendritic branches (Fig. 9A, arrow) of this $\alpha$-GC were protruded to more distal layers of the IPL, apart from the proximal plane contributing to its main dendritic distribution. A stereo-pair of dendritic extension in Figure $9 B$ can clearly demonstrate the protrusion to the distal layers, which corresponds to the arrow indication of Figure $9 \mathrm{~A}$. In a highermagnification view of Figure $9 D$, these protruded dendritic terminals were sometimes self-contacted with one another, making a contact site (arrow).

Perikaryal Cx36 vascular immunolocalization was observed in the LY-filled soma (Fig. 9C) because pseudocoloring (yellow) discriminates the $\mathrm{Cx} 36$ localization from the brilliant LY labeling. It is evident that some Cx36 punctate signals (yellow) in a proximal layer of the IPL also occur on the LY-labeled peripheral dendrites in a high-resolution confocal imaging of Figure $9 D$. This observation demonstrates the occurrence of dendritic Cx36 immunolocalization on the $\alpha$-GC. The high-resolution imaging also shows that Cx36 immunosignal was located in the contact site between self-contacting dendrites (Fig. 9D, arrow), where autaptic gap junctions are possibly localized. All $\alpha$-GCs examined with double-labeling fluorescence of LY injection and Cx36 im- 

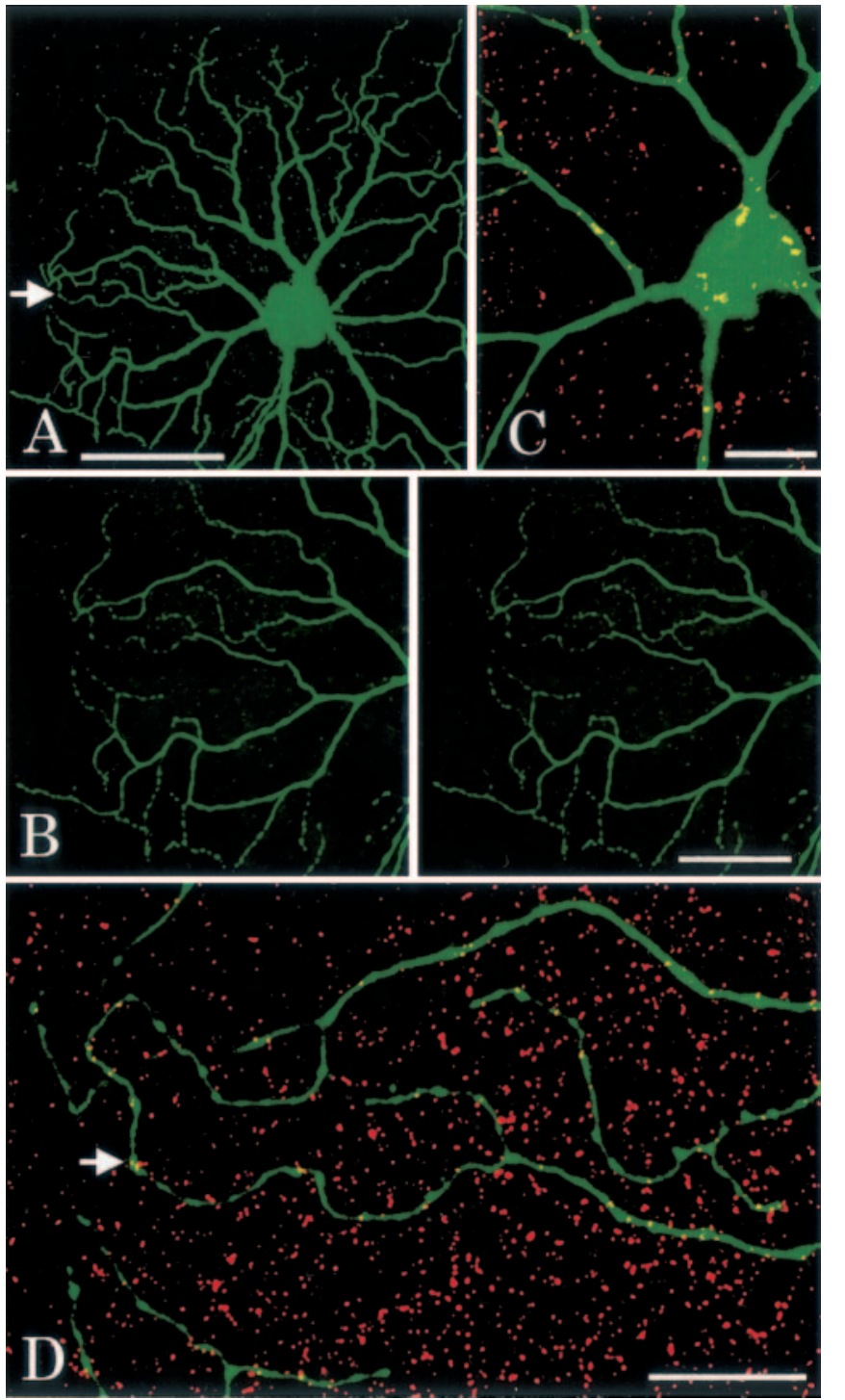

Figure 9. $\alpha$-GCs express $(x 36$. A, A projected image of $\mathrm{LY}$ labeling of inner-type $\alpha$-GCS indicates its dendritic expansion that involves self-contacts between peripheral dendrites (arrow). $B$, Stereo pair demonstrating their dendrites, shown in $A$. Note that self-contacting dendrites (arrow) are protruded to more distal layers of the IPL, apart from the proximal plane contributing to the main dendritic distribution of the cell. C, Vesicular immunoreactivity is localized in the cytoplasm of soma and primary dendrites. The immunoreactivity (red) was merged in LY labeling (green). Note that localization of perikaryal immunolabeling is restricted to the perinuclear region. $D$, Punctate immunoreactivity is localized along peripheral dendrites An immunopunctum is localized at the site for self-contacts between dendritic terminals (arrow), which shows the presence of gap junctions at the contact. Scale bars: $A, 100 \mu \mathrm{m} ; B, 50$ $\mu \mathrm{m} ; C, D, 20 \mu \mathrm{m}$.

munolocalization in the present study $(n=32)$ showed perikaryal Cx36 immunoreactivity.

\section{Localization of $\mathrm{Cx} 36$ in dendrodendritic contacts between $\alpha$-GCs}

To address the occurrence of dendrodendritic gap junctions between electrically coupled $\alpha$-GCs, we examined double-labeling immunofluorescence by confocal microscopy using anti-Cx36 antisera on LY-labeled pairs of $\alpha$-GCs after dual patch-clamp recordings from the two cells (Figs. 3-5). Figure 10 shows optical images of two successive LY labelings of a neighboring outer-type $\alpha$-GC pair and punctate Cx36 immunoreactivity. Distribution of these cells with an intercell distance of $140 \mu \mathrm{m}$ (Fig. 10A) corre- sponded to that of tracer-coupled outer-type $\alpha$-GCs (see above). In high-resolution projected images of Figure 10, $B$ and $C$, mutual dendritic interconnections between the $\alpha$-GCs occurred in either manner of tip-to-trunk (tip-contact) or trunk-to-trunk (crossing contact as making dendritic crossing point). Ten dendrodendritic contacts were identified in single optical sections. Seven immunopuncta (yellow vesicles, indicated by filled arrows) among numerous punctate signals in the IPL overlapped in the contact sites, as shown in higher-magnification views of Figure $10, D-H$ and $K$. The three remaining contacts did not show any Cx36 immunoreactivity (Fig. 10B, C, open arrowheads). A focal series of successive single optical sections in Figure 10, $I-M$, provide confidence that a Cx36 punctum (yellow vesicles) was just localized at the tip-contact site between the two LY-labeled dendrites, not above or below it. Thus, the fluorescent punctate localization overlapped in the contact site between $\alpha$-GCs, as corresponds to the electron microscopic observation (Fig. $8 D, E$ ). These results demonstrate the occurrence of direct dendrodendritic gap junctions involving Cx36 channels between electrically coupled $\alpha$-GCs of the same type.

We evaluated the incidence of gap junctions between the electrically coupled $\alpha$-GC pairs by localizing Cx36 fluorescent immunopuncta at the dendrodendritic contact sites in all preparations examined in the present study $(n=12)$. The average number of gap junction sites estimated by counting yellow immunopuncta at the directly contacting dendrites between the electrically coupled pairs was seven (range, 2-12). Apart from the directly contacting sites between the dendrites of the cell pairs, however, some of Cx36 immunopuncta were distributed on the dendrites of either cell. In ultrastructural thin-sectioning studies of Neurobiotin-labeled peripheral dendrites of $\alpha$-GCs, gap junction plaques between labeled and unlabeled cells were frequently encountered (see above). The dendritic Cx36 immunolocalization apart from the LY-labeled interconnected sites thus suggests possible localization of gap junctions among electrically coupled but unlabeled $\alpha$-GCs, or cells involving amacrine cells.

Assuming that the dendrodendritic gap junction plaques between $\alpha$-GCs are circular $(0.86 \mu \mathrm{m}$ in an average diameter $)$ and that the density of connexon particles is the same as seen in a freeze-fracture replica micrograph from the IPL of the rat retina (S. Hidaka, unpublished observation), similar to that of brain Cx36 (Rash et al., 2000), 3000 connexons would be expected per junction. If each of these is homomeric and homotypic of Cx36 with a single-channel conductance of $15 \mathrm{pS}$ as elsewhere (Srinivas et al., 1999; Teubner et al., 2000), the conductance of each gap junction would be $45 \mathrm{nS}$ when it was fully open. This estimation will lead us to calculate much higher junctional conductance between an $\alpha$-GC pair connected with seven mutual junctions than the measured maximum conductance ( $2.45 \mathrm{nS})$. Given that the open probability of $\mathrm{Cx}$ channels is likely to be less than unity, the measured conductance could allow us to estimate a fraction of open channels as $0.8 \%$. This fraction of open gap junction channels is small, when we consider whether mutual electrotonic transmission acts to tightly synchronize the activity in the homologous intercellular network. The low density of open channels between the two $\alpha$-GCs might reflect the possible electrical connections with other neighboring cells.

\section{Discussion}

Direct gap junction connections between $\alpha$-GCs of the same type

Our multiplex knowledge of anatomical and electrophysiological properties of gap junctions of $\alpha$-GCs presented clear evidence of 
the occurrence of electrical couplings in which ultrastructurally identified gap junctions are localized between Neurobiotin-coupled cells. Tracer coupling between examined cells after intracellular injection, developed by Vaney (1991), has been used as an indicator of the occurrence of junctional connections between target cells (Dacey and Brace, 1992; Penn et al., 1994; Vaney, 1994; Xin and Bloomfield, 1997). To date, there has been no report to describe the presence of direct gap junctions between GCs, because light-microscopically examined dendritic contacts between tracer-coupled GCs were not ultrastructurally examined.

Gap junctions have been implied to exist between $\alpha$-GCs and unlabeled amacrine cells based on the following observations: (1) $\alpha$-GCs were extensively tracer coupled to small cells rather than other GCs; (2) labeling of neighboring $\alpha$-GCs coupled to the injected cell was weak. Neurobiotin transfer was just detected in somata of coupled $\alpha$-GCs; and (3) the cellular origin of adjacent processes contacted with $\alpha$-GCs in previous thinsectioning ultrastructural studies was not determined (Jacoby et al., 1996). In the present study, our methods of highvoltage electron microscopy of the Neurobiotin-coupled specimens (Hidaka et al., 1993; Hidaka and Miyachi, 2003) resolved three-dimensional structure of direct dendritic interconnections through homologous gap junctions. Penn et al. (1994) showed possible mutual contacts at dendritic crossing points between ferret $\alpha$-GCs. Their crossing contacts between the $\alpha$-GCs are possible sites for gap junctions.

$\alpha$-GCs express Cx36. The punctate immunoreactivity was used as an indicator of the precise location of gap junctions in physiological cell pairs using doublelabeling fluorescence in situ. Contact sites between $\alpha$-GCs of the same type localized the immunopuncta. There are several articles showing Cx36 to be expressed in AII amacrine cells (Feigenspan et al., 2001; Mills et al., 2001; Güldenagel et al., 2001). In contrast, reporter expression by replacement of the $\mathrm{Cx} 36$ coding sequence in knock-out mice showed that its histological localization was found in a variety of retinal neurons, in addition to AII cells, e.g., photoreceptors, cone bipolar cells, and neurons in the GCL (Deans et al.,

2002). Recent experiments of cell types expressing Cx36 or the fish homologs (Feigenspan et al., 2004; O’Brien et al., 2004) have described similar observation in those distal neurons. However, the possibility of $\mathrm{Cx} 36$ expression in $\alpha$-GCs was not examined in those reports. In another Cx36-knock-out experiment (Güldenagel et al., 2001), function of retinal Cx36 channels in visual

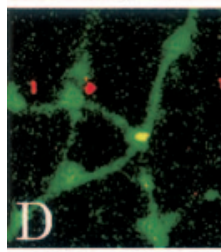

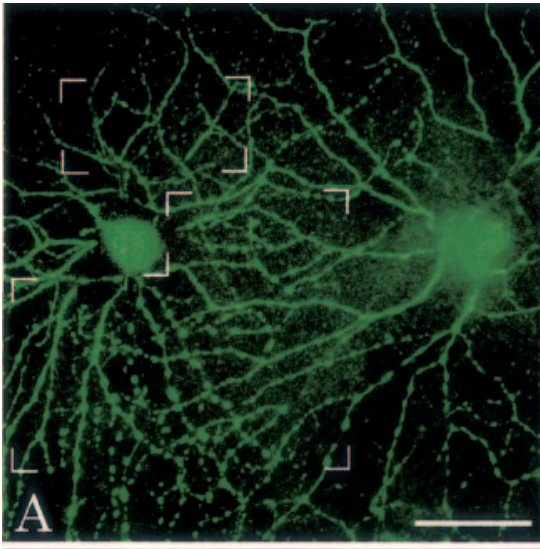
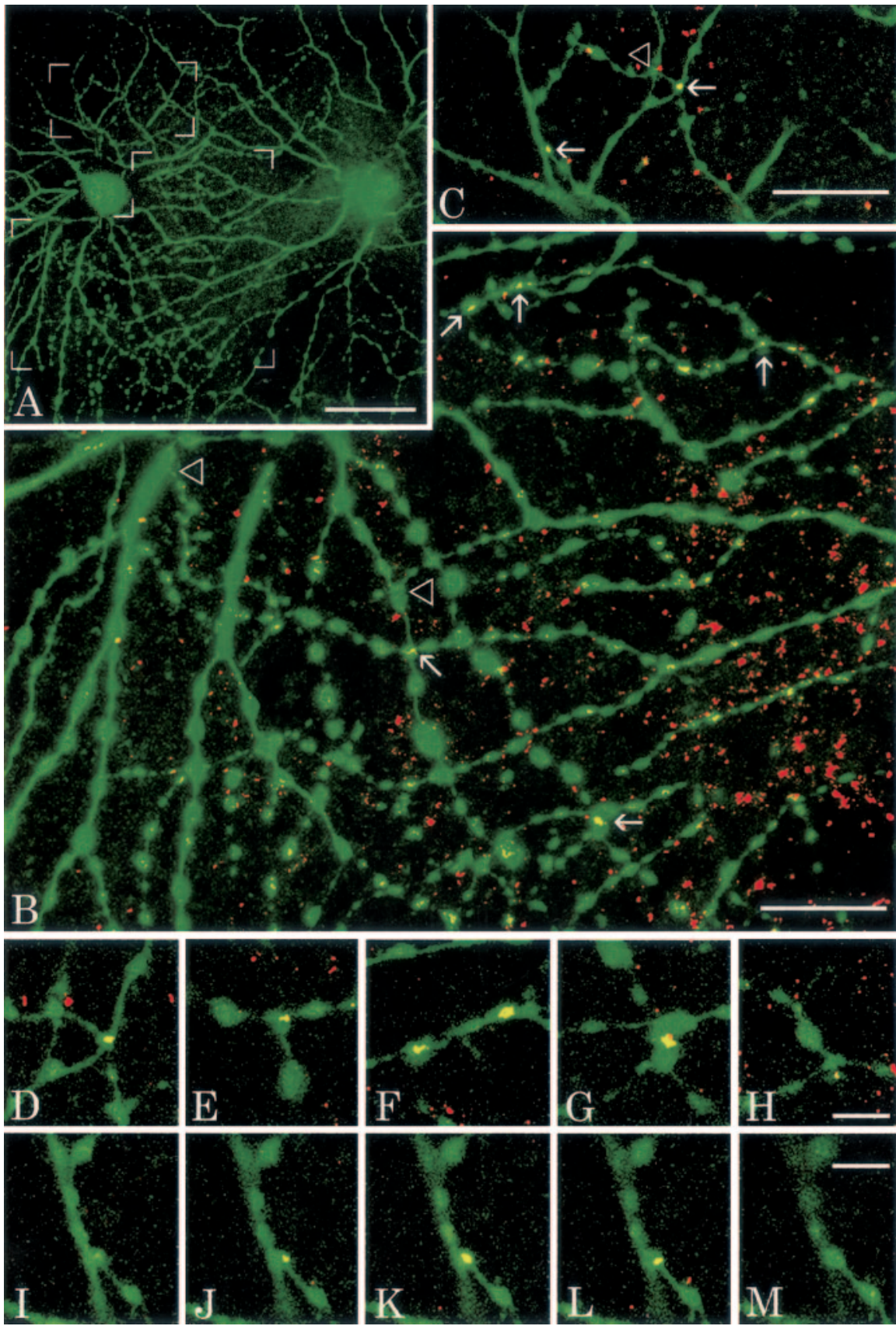

Figure 10. Gap junctions involving (x36 are localized in dendrodendritic contacts between electrically coupled $\alpha$-GCs. A, A confocal projected image demonstrating LY labeling of a pair of electrically coupled outer-type $\alpha$-GCs. This cell pair showed bidirectional electrical synapses by dual recordings. $B, C$, High-power magnification of the enlargement of the framed area in $A$, demonstrating dendritic interconnections between the two cells (green) with localization of $(x 36$ immunoreactivity (red). The cells make 10 dendrodendritic contacts with one another, all of which are indicated by arrows or arrowheads. The contact site is present either at the dendritic tip or mutual crossing point. Note that seven contact sites localize immunopuncta (yellow; indicated by filled arrows), whereas three sites show no immunoreactivity (open arrowheads). $D-H$, High-magnification views of single confocal optical images of the six contact sites designated in $B$ and $C$, demonstrating that each direct contact between the dendrites contain a $(x 36$ punctum (yellow). I-M, A focal series of single confocal optical images of the dendritic contact designated in ( shows that the Cx36 punctate signal (yellow) occurs only where the two $\alpha$-GC dendrites actually touch each other in the three-dimensional space. Scale bars: $A, 50 \mu \mathrm{m} ; B, C, 20 \mu \mathrm{m} ; D-M, 5 \mu \mathrm{m}$.

processing were not in any way linked to $\alpha$-GCs, but from contribution of AII cells. Our recent study finding expression of Cx36 in the GCL (Hidaka et al., 2002) was explicitly clarified to localize the Cx to $\alpha$-GCs.

Apart from Cx36, it has been of broad interest whether other Cxs are expressed in mammalian retinal neurons (Güldenagel et 
al., 2000; Deans and Paul, 2001; Massey et al., 2003). Zahs et al. (2003) described that $\mathrm{Cx} 30, \mathrm{Cx} 43$, and $\mathrm{Cx} 45$ are expressed in Müller cells and astrocytes. Cx45 is also expressed in neurons of the olfactory epithelium and bulb (Zhang and Restrepo, 2002). Another cloned connexin, $\mathrm{Cx} 47$, is not expressed in the retina, although the $\mathrm{Cx}$ was reported as neural, being expressed in central neurons (Teubner et al., 2001). However, it is clear that Cx47 is a product of olygodendrocytes (Menichella et al., 2003; Odermatt et al., 2003). A recent article showed that horizontal cells express Cx57 (Hombach et al., 2004). It remains elusive whether only Cx36 is localized in gap junctions between $\alpha$-GCs.

\section{Gap junctions between $\alpha$-GCs as electrical synapses}

From the present study of structure-function correlation in gap junctions (cf. Sotelo and Korn, 1978), several lines of evidence point to the formation of functional electrical synapses between $\alpha$-GCs of the same type. First, the observed bidirectional electrical coupling in $\alpha$-GC pairs appears to be attributable to current flow through direct gap junctions, because these responses have the functional properties expected for electrical coupling mediated by gap junctions. Second, electrical coupling was only observed between $\alpha$-GCs of the same type. Our results are consistent with the initial finding of electrical coupling between cat Y-GCs (Mastronarde, 1983a,b,c). Third, we never observed electrical coupling between different types of $\alpha$-GCs, the dendrites of which were not in physical contact with each other.

In this study, we also observed heterologous tracer coupling to amacrine cells, as found in the preparations of other studies. Labeling of dendrites of those amacrine cells was weak. Apart from contact sites between Neurobiotin-labeled $\alpha$-GC processes, we ultrastructurally observed gap junctions between labeled $\alpha$-GC and unlabeled processes. From these results, we cannot exclude the absence of heterologous gap junctions between $\alpha$-GCs and amacrine cells, although it remains possible that Neurobiotin could be incorporated into those cells by microelectrode double penetration. Interestingly, the latencies for spike synchronization of $\alpha$-GC pairs showed a somewhat broad range among individual spiking, compared with those reported in inferior olivary neuron pairs synchronizing tightly with a lag of $<2 \mathrm{msec}$ (Long et al., 2002). The indirect pathway through amacrine-to$\alpha$-GC gap junctions might explain a longer time delay in spiking between neighboring $\alpha$-GCs.

\section{Electrical synapses between $\alpha$-GCs for both $\mathrm{ON}$ - and OFF-center types}

$\mathrm{Hu}$ and Bloomfield (2003) have recently shown in support of our results using rabbit retinas that spikes from OFF-center $\alpha$-GCs were synchronously produced with short latency, suggesting the occurrence of electrical synapses in the population. DeVries (1999) also demonstrated concerted firing with the crosscorrelation functions among neighboring rabbit OFF-center Y-cells. However, the possible occurrence of gap junctions in rabbit cells was not described in $\mathrm{ON}$-center types. Both rat $\mathrm{ON}$ and OFF-center $\alpha$-GCs make electrical synapses between neighbors. Rat $\mathrm{ON}$-center types are distributed somewhat more sparsely and showed a little lower probability of Neurobiotin coupling. This is consistent with that by a reduced silver method (Peichl, 1989). If rabbit OFF-center cells are closely located in the population, correlation of spikes and diffusion of Neurobiotin would be positively found for electrical synapses. Any difference in distribution of rabbit $\mathrm{ON}$ - and OFF-center types was not studied (Peichl et al., 1987).

\section{Functional consequences of electrical synapses between $\boldsymbol{\alpha}$-GCs}

Electrical synapses are a common mediator of synchronized activity in the interconnected population, and they are considered effective in synchronizing subthreshold membrane potentials (Galarreta and Hestrin, 1999, 2001; Gibson et al., 1999; Veruki and Hartveit, 2002a,b; Connors and Long, 2004). Consistent with the other studies, the present study suggests that temporally precise synchronization of activity among $\alpha$-GCs can be important in generation of action potentials.

An obvious question to ask is whether the lateral spread of signals in the network of electrically coupled $\alpha$-GCs can decrease the visual acuity of spatial signals in the retina. Although we did not record light-evoked responses from rat $\alpha$-GCs or measure their receptive fields, the receptive fields of the synchronous spiking from salamander GCs are smaller than those of individual GCs and are located at their intersection (Meister et al., 1995; Meister, 1996). Thus, synchronous spiking can preserve high spatial resolution and compress visual signals for efficient transmission through the optic nerve (Meister and Berry, 1999). In contrast, DeVries and Baylor (1997) demonstrated that receptive fields of neighboring rabbit Y-GCs are overlapped to extend the center of an individual cell. It would seem likely that the extension of the receptive field of rabbit individual Y-GC is mediated by electrical synapses in the cell population ( $\mathrm{Hu}$ and Bloomfield, 2003). On the other hand, Nirenberg et al. (2001) has shown that GCs can capture most of the visual information (>90\%) about the stimuli that these cells carry in the light-adapted condition when the cells act independently to encode information by ignoring correlated spiking in the cell population. This analysis pooled disparate GC types to encode visual signals in the retina. It remains to know about visual information that populations of electrically coupled $\alpha$-GCs convey to brain centers. Large receptive fields of $\alpha$-GCs provide the possibility of decreasing spatial resolution by electrical interaction and their dendritic plexus forms networks that uniformly covers the retina, yet only form $2-4 \%$ of the total GC population (Peichl, 1989). Because only GCs with high density and small dendritic fields are able to provide high visual acuity, it would seem that $\alpha$-GCs are not responsible for conveying high visual acuity.

The functional role of electrical synapses between $\alpha$-GCs appears to be significant for scotopic vision. In the dark-adapted retina, the activity of the receptive field surrounds of $\alpha$-GCs is lost and the size of the receptive field centers significantly increases (Barlow et al., 1957; Peichl and Wässle, 1983; Muller and Dacheux, 1997). It is interesting how electrical synapses between $\alpha$-GCs contribute to visual tasks under scotopic conditions. The contrast sensitivity of a neuron that integrates signals from photoreceptors in its field depends on the area of the receptive field; therefore, large receptive fields would permit higher-contrast sensitivity by improving the signal/noise ratio. Modeling studies of bipolar cells (Umino et al., 1994; Poznanski and Umino, 1997) concluded that electrical coupling could smooth a signal over coupled cells, reducing the difference between central and peripheral cells by up to $80 \%$ before visual acuity was compromised. Therefore, low level of electrical coupling between $\alpha$-GCs under mesopic conditions can contribute to noise reduction without comprising visual acuity.

Electrical coupling is expected for synchronization of firing patterns between inhibitory interneurons in modeling studies (Traub et al., 2001; Amitai et al., 2002), presumably influenced by intrinsic ionic currents. $\alpha$-GCs are likely to express persistent sodium channels (Hidaka and Ishida, 1998) shown to reduce the 
level of spike synchrony in computer models (Pfeuty et al., 2003). It remains elusive whether electrical interactions between $\alpha$-GCs play a functional role in synchronization of their ionic current signals.

\section{References}

Adams JC (1981) Heavy metal intensification of DAB-based HRP reaction product. J Histochem Cytochem 29:775.

Al-Ubaidi MR, White TW, Ripps H, Poras I, Avner P, Gomes D, Bruzzone R (2000) Functional properties, developmental regulation, and chromosomal localization of murine connexin 36 , a gap-junctional protein expressed preferentially in retina and brain. J Neurosci Res 59:813-826.

Amitai Y, Gibson JR, Beierlein M, Patrick SL, Ho AM, Connors BW, Golomb D (2002) The spatial dimensions of electrically coupled networks of interneurons in the neocortex. J Neurosci 22:4142-4152.

Barlow HB, Fitzhugh R, Kuffler SW (1957) Change of organization in the receptive fields of the cat's retina during dark adaptation. J Physiol (Lond) 137:338-354.

Belluardo N, Mudo G, Trovato-Salinaro A, Le Gurun S, Charollais A, Beinier V, Amato G, Haefliger JA, Meda P, Condorelli DF (2000) Expression of connexin 36 in the adult and developing rat brain. Brain Res 865:121-138.

Bennett MV (2000) Seeing is relieving: electrical synapses between visualized neurons. Nat Neurosci 3:7-9.

Bennett MVL, Barrio LC, Bargiello TA, Spay DC, Hertzberg E, Saez JC (1991) Gap junctions: new tools, new answers, new questions. Neuron 6:305-317.

Brivanlou IH, Warland DK, Meister M (1998) Mechanisms of concerted firing among retinal ganglion cells. Neuron 20:527-539.

Bruzzone R, White TW, Paul DL (1996) Connections with connexins: the molecular basis of direct intercellular signaling. Eur J Biochem 238:1-27.

Buhl DL, Harris KD, Hormuzdi SG, Monyer H, Buzsaki G (2003) Selective impairment of hippocampal gamma oscillations in connexin-36 knockout mouse in vivo. J Neurosci 23:1013-1018.

Condorelli DF, Parenti R, Spinella F, Trovato-Sanlinaro A, Belluardo N, Cardile V, Cicirata F (1998) Cloning a new gap junction gene (Cx36) highly expressed in mammalian brain neurons. Eur J Neurosci 10:1202-1208.

Connors BW, Long MA (2004) Electrical synapses in the mammalian brain. Annu Rev Neurosci 27:393-418.

Dacey DM, Brace S (1992) A coupled network for parasol but not midget ganglion cells in the primate retina. Vis Neurosci 9:279-290.

Deans MR, Paul DL (2001) Mouse horizontal cells do not express connexin26 or connexin36. Cell Commun Adhes 8:361-366.

Deans MR, Gibson JR, Sellitto C, Connors BW, Paul DL (2001) Synchronous activity of inhibitory networks in neocortex requires electrical synapses containing connexin36. Neuron 31:477-485.

Deans MR, Volgyi B, Goodenough DA, Bloomfield SA, Paul DL (2002) Connexin36 is essential for transmission of rod-mediated visual signals in the mammalian retina. Neuron 36:703-712.

Dermietzel R, Spray DC (1993) Gap junctions in the brain: where, what type, how many, and why? Trends Neurosci 16:185-192.

DeVries SH (1999) Correlated firing in rabbit retinal ganglion cells. J Neurophysiol 81:908-920.

DeVries SH, Baylor DA (1997) Mosaic arrangement of ganglion cell receptive fields in rabbit retina. J Neurophysiol 78:2048-2060.

Dowling JE (1987) The retina: an approachable part of the brain. Boston: Harvard UP.

Famiglietti EV, Kaneko A, Tachibana M (1977) Neuronal architecture of ON and OFF pathways to ganglion cells in carp retina. Science 198:1267-1269.

Feigenspan A, Teubner B, Willecke K, Weiler R (2001) Expression of neuronal connexin 36 in AII amacrine cells of the mammalian retina. J Neurosci 21:230-239.

Feigenspan A, Janssen-Bienhold U, Hormuzdi S, Monyer H, Degen J, Söhl G, Willecke K, Ammermuller J, Weiler R (2004) Expression of connexin36 in cone pedicles and OFF-cone bipolar cells of the mouse retina. J Neurosci 24:3325-3334.

Freed MA, Pflug R, Kolb H, Nelson R (1996) ON-OFF amacrine cells in cat retina. J Comp Neurol 364:556-566.

Galarreta M, Hestrin S (1999) A network of fast-spiking cells in the neocortex connected by electrical synapses. Nature 402:72-75.

Galarreta M, Hestrin S (2001) Electrical synapses between GABA-releasing interneurons. Nat Rev Neurosci 2:425-433.
Gibson JR, Beierlein M, Connors BW (1999) Two networks of electrically coupled inhibitory neurons in neocortex. Nature 402:75-79.

Goodenough DA, Goliger JA, Paul DL (1996) Connexins, connexons, and intercellular communication. Annu Rev Biochem 65:475-502.

Güldenagel M, Söhl G, Plum A, Traub O, Teubner B, Weiler R, Willecke K (2000) Expression pattern of connexin genes in mouse retina. J Comp Neurol 425:193-201.

Güldenagel M, Ammermuller J, Feigenspan A, Teubner B, Degen J, Söhl G, Willecke K, Weiler R (2001) Visual transmission deficits in mice with targeted disruption of the gap junction gene connexin36. J Neurosci 21:6036-6044.

Hidaka S, Ishida AT (1998) Voltage-gated $\mathrm{Na}^{+}$current availability after step- and spike-shaped conditioning depolarizations of retinal ganglion cells. Pflügers Arch 436:497-508.

Hidaka S, Miyachi E (2003) Homotypic gap junction connections between retinal amacrine cells. In: The neural basis of early vision, Keio International Symposium, Vol 11 (Kaneko A, ed), pp 126-133. Tokyo: Springer.

Hidaka S, Tauchi T (1993) Gap junctional connections between longsurvived axotomized ganglion cells and amacrine cells in the mammalian retina (in Japanese). Jpn Soc Neural Growth Regener Transplant 5:51-52.

Hidaka S, Christensen BN, Naka K (1986) The synaptic ultrastructure in the outer plexiform layer of the catfish retina: a three-dimensional study with HVEM and conventional EM of Golgi-impregnated bipolar and horizontal cells. J Comp Neurol 247:181-199.

Hidaka S, Shingai R, Dowling JE, Naka KI (1989) Junctions form between catfish horizontal cells in culture. Brain Res 498:53-63.

Hidaka S, Maehara M, Umino O, Hashimoto Y (1993) Lateral gap junction connections between retinal amacrine cells summating sustained responses. NeuroReport 5:29-32.

Hidaka S, Kato T, Miyachi E (2002) Expression of gap junction protein connexin36 in adult rat retinal ganglion cells. J Integr Neurosci 1:3-22.

Hombach S, Janssen-Bienhold U, Söhl G, Schubert T, Bussow H, Ott T, Weiler R, Willecke K (2004) Functional expression of connexin57 in horizontal cells of the mouse retina. Eur J Neurosci 19:2633-2640.

Hormuzdi SG, Pais I, LeBeau FE, Towers SK, Rozov A, Buhl EH, Whittington MA, Monyer H (2001) Impaired electrical signaling disrupts gamma frequency oscillations in connexin 36-deficient mice. Neuron 31:487-495.

Hu EH, Bloomfield SA (2003) Gap junctional coupling underlies the shortlatency spike synchrony of retinal alpha ganglion cells. J Neurosci 23:6768-6777.

Jacoby R, Stafford D, Kouyama N, Marshak D (1996) Synaptic inputs to ON parasol ganglion cells in the primate retina. J Neurosci 16:8041-8056.

Johansson K, Bruun A, Ehinger B (1999) Gap junction connexin43 is heterogeneously expressed among glial cells in the adult rabbit retina. J Comp Neurol 407:395-403.

Kolb H (1979) The inner-plexiform layer in the retina of the cat: electron microscopic observations. J Neurocytol 8:295-329.

Kolb H, Nelson R (1993) OFF-alpha and OFF-beta ganglion cells in cat retina: II. Neural circuitry as revealed by electron microscopy of HRPstains. J Comp Neurol 329:85-110.

Kumar NM, Gilula NB (1996) The gap junction communication channel. Cell 84:381-388.

Lee EJ, Han JW, Kim HJ, Kim IB, Lee MY, Oh SJ, Chung JW, Chun MH (2003) The immunocytochemical localization of connexin 36 at rod and cone gap junctions in the guinea pig retina. Eur J Neurosci 18:2925-2934.

Llinas R, Baker R, Sotelo C (1974) Electrotonic coupling between neurons in cat inferior olive. J Neurophysiol 37:560-571.

Long MA, Deans MR, Paul DL, Connors BW (2002) Rhythmicity without synchrony in the electrically uncoupled inferior olive. J Neurosci 22:10898-10905.

Maier M, Güldenagel M, Söhl G, Siegmund H, Willecke K, Draguhn A (2002) Reduction of high-frequency network oscillations (ripples) and pathological network discharges in hippocampal slices from connexin 36-deficient mice. J Physiol (Lond) 541:521-528.

Mann-Metzer P, Yarom Y (1999) Electrotonic coupling interacts with intrinsic properties to generate synchronized activity in cerebellar networks of inhibitory interneurons. J Neurosci 19:3298-3306.

Massey SC, Mills SL (1999) Antibody to calretinin stains AII amacrine cells in the rabbit retina: double-label and confocal analyses. J Comp Neurol 411:3-18.

Massey SC, O’Brien JJ, Trexler EB, Li W, Keung JW, Mills SL, O’Brien J 
(2003) Multiple neuronal connexins in the mammalian retina. Cell Commun Adhes 10:425-430.

Mastronarde DN (1983a) Correlated firing of cat retinal ganglion cells. I. Spontaneously active inputs to $\mathrm{X}$ - and Y-cells. J Neurophysiol 49:303-324.

Mastronarde DN (1983b) Correlated firing of cat retinal ganglion cells. II. Responses of X-and Y-cells to single quantal events. J Neurophysiol 49:325-349.

Mastronarde DN (1983c) Interactions between ganglion cells in cat retina. J Neurophysiol 49:350-365.

Mastronarde DN (1989) Correlated firing of cat retinal ganglion cells. Trends Neurosci 12:75-80.

Meister M (1996) Multineuronal codes in retinal signaling. Proc Natl Acad Sci USA 93:609-614.

Meister M, Berry MJ (1999) The neural code of the retina. Neuron 22:435-450.

Meister M, Lagnado L, Baylor DA (1995) Concerted signaling by retinal ganglion cells. Science 270:1207-1210.

Menichella DM, Goodenough DA, Sirkowski E, Scherer SS, Paul DL (2003) Connexins are critical for normal myelination in the CNS. J Neurosci 23:5963-5973.

Mills SL, O’Brien JJ, Li W, O’Brien J, Massey SC (2001) Rod pathways in the mammalian retina use connexin 36. J Comp Neurol 436:336-350.

Muller JF, Dacheux RF (1997) Alpha ganglion cells of the rabbit retina lose antagonistic surround responses under dark adaptation. Vis Neurosci 14:395-401.

Neuenschwander S, Singer W (1996) Long-range synchronization of oscillatory light responses in the cat retina and lateral geniculate nucleus. Nature 379:728-732.

Nirenberg S, Carcieri SM, Jacobs AL, Latham PE (2001) Retinal ganglion cells act largely as independent encoders. Nature 411:698-701.

Nolan MF, Logan SD, Spanswick D (1999) Electrophysiological properties of electrical synapses between rat sympathetic preganglionic neurones in vitro. J Physiol (Lond) 519:753-764.

O’Brien J, Al-Ubaidi MR, Ripps H (1996) Connexin35: a gap-junctional protein expressed preferentially in the skate retina. Mol Biol Cell 7:233-243.

O’Brien J, Bruzzone R, White TW, Al-Ubaidi MR, Ripps H (1998) Cloning and expression of two related connexins from the perch retina define a distinct subgroup of the connexin family. J Neurosci 18:7625-7637.

O’Brien J, Nguyen HB, Mills SL (2004) Cone photoreceptors in bass retina use two connexins to mediate electrical coupling. J Neurosci 24:5632-5642.

Odermatt B, Wellershaus K, Wallraff A, Seifert G, Degen J, Euwens C, Fuss B, Bussow H, Schilling K, Steinhauser C, Willecke K (2003) Connexin 47 (Cx47)-deficient mice with enhanced green fluorescent protein reporter gene reveal predominant oligodendrocytic expression of $\mathrm{Cx} 47$ and display vacuolized myelin in the CNS. J Neurosci 23:4549-4559.

Peichl L (1989) Alpha and delta ganglion cells in the rat retina. J Comp Neurol 286:120-139.

Peichl L, Wässle H (1983) The structural correlate of the receptive field centre of ganglion cells in the cat retina. J Physiol (Lond) 341:309-324.

Peichl L, Ott H, Boycott BB (1987) Alpha ganglion cells in mammalian retinae. Proc R Soc Lond B Biol Sci 231:169-197.

Penn AA, Wong ROL, Shatz CL (1994) Neuronal coupling in the developing mammalian retina. J Neurosci 14:3805-3815.

Pfeuty B, Mato G, Golomb D, Hansel D (2003) Electrical synapses and synchrony: the role of intrinsic currents. J Neurosci 23:6280-6294.

Poznanski RR, Umino O (1997) Syncytial integration by a network of coupled bipolar cells in the retina. In: Progress in Neurobiology, Vol 53 (Kerkut GA, Phillis JW, eds), pp 273-291. Oxford: Pergamon.

Rash JE, Staines WA, Yasumura T, Patel D, Furman CS, Stelmack GL, Nagy JI (2000) Immunogold evidence that neuronal gap junctions in adult rat brain and spinal cord contain connexin-36 but not connexin-32 or connexin-43. Proc Natl Acad Sci USA 97:7573-7578.

Sakmann B, Neher E (1995) Single-channel recording, Ed 2. New York: Plenum.

Söhl G, Degen J, Teubner B, Willecke K (1998) The murine gap junction gene connexin 36 is highly expressed in mouse retina and regulated during brain development. FEBS Lett 428:27-31.

Sotelo C, Korn H (1978) Morphological correlates of electrical and other interactions through low-resistance pathways between neurons of the vertebrate central nervous system. Int Rev Cytol 55:67-107.

Srinivas M, Rozental R, Kojima T, Dermietzel R, Mehler M, Condorelli DF, Kessler JA, Spray DC (1999) Functional properties of channels formed by the neuronal gap junction protein connexin36. J Neurosci 19:9848-9855.

Tabata T, Ishida AT (1996) Transient and sustained depolarization of retinal ganglion cells by $I_{\mathrm{h}}$. J Neurophysiol 75:1932-1943.

Tauchi M, Masland RH (1984) The shape and arrangement of the cholinergic neurons in the rabbit retina. Proc $\mathrm{R}$ Soc Lond B Biol Sci 223:101-119.

Tauchi M, Morigiwa K, Fukuda Y (1992) Morphological comparisons between outer and inner ramifying alpha cells of the albino rat retina. Exp Brain Res 88:67-77.

Teubner B, Degen J, Söhl G, Güldnagel M, Bukauskas FF, Trexler EB, Verselis VK, De Zeeuw CI, Lee CG, Kozak CA, Petrasch-Parwez E, Dermietzel R, Willecke K (2000) Functional expression of the murine connexin 36 gene coding for a neuron-specific gap junctional protein. J Membr Biol 176:249-262.

Teubner B, Odermatt B, Güldnagel M, Söhl G, Degen J, Bukauskas F, Kronengold J, Verselis VK, Jung YT, Kozak CA, Schilling K, Willecke K (2001) Functional expression of the new gap junction gene connexin 47 transcribed in mouse brain and spinal cord neurons. J Neurosci 21:1117-1126.

Traub RD, Kopell N, Bibbig A, Buhl EH, LeBeau FE, Whittington MA (2001) Gap junctions between interneuron dendrites can enhance synchrony of gamma oscillations in distributed networks. J Neurosci 21:9478-9486.

Umino O, Maehara M, Hidaka S, Kita K, Hashimoto Y (1994) The network properties of bipolar-bipolar coupling in the retina of teleost fishes. Vis Neurosci 11:533-548.

Vaney DI (1991) Many diverse types of retinal neurons show tracer coupling when injected with biocytin or Neurobiotin. Neurosci Lett 125:187-190.

Vaney DI (1992) Photochromic intensification of diaminobenzidine reaction product in the presence of tetrazolium salts: applications for intracellular labeling and immunohistochemistry. J Neurosci Methods 44:217-223.

Vaney DI (1994) Patterns of neuronal coupling in the retina. In: Progress in Retinal Eye Research, Vol 13 (Osborne NN, Chader GJ, eds), pp 301-355. Oxford: Pergamon.

Velte TJ, Masland RH (1999) Action potentials in the dendrites of retinal ganglion cells. J Neurophysiol 81:1412-1417.

Veruki ML, Hartveit E (2002a) AII (Rod) amacrine cells form a network of electrically coupled interneurons in the mammalian retina. Neuron 33:935-946.

Veruki ML, Hartveit E (2002b) Electrical synapses mediate signal transmission in the rod pathway of the mammalian retina. J Neurosci 22:10558-10566.

Wässle H, Peichl L, Boycott BB (1981) Dendritic territories of cat retinal ganglion cells. Nature 292:344-345.

Wässle H, Grunert U, Rohrenbeck J (1993) Immunocytochemical staining of AII-amacrine cells in the rat retina with antibodies against parvalbumin. J Comp Neurol 332:407-420.

White TW, Paul DL (1999) Genetic diseases and gene knockouts reveal diverse connexin functions. Annu Rev Physiol 61:283-310.

White TW, Deans MR, O’Brien J, Al-Ubaidi MR, Goodenough DA, Ripps H, Bruzzone R (1999) Functional characteristics of skate connexin35, a member of the gamma subfamily of connexins expressed in the vertebrate retina. Eur J Neurosci 11:1883-1890.

Xin D, Bloomfield SA (1997) Tracer coupling pattern of amacrine and ganglion cells in the rabbit retina. J Comp Neurol 383:512-528.

Zahs KR, Kofuji P, Meier C, Dermietzel R (2003) Connexin immunoreactivity in glial cells of the rat retina. J Comp Neurol 455:531-546.

Zhang C, Restrepo D (2002) Expression of connexin 45 in the olfactory system. Brain Res 929:37-47. 